Supporting Information for

\title{
Fine-Tuning Nickel Phenoxyimine Olefin Polymerization Catalysts: Performance Boosting by Alkali Cations
}

\author{
Zhongzheng Cai, Dawei Xiao, Loi H. Do* \\ Department of Chemistry, University of Houston, Houston, Texas, 77204
}

TABLE OF CONTENTS

$\underline{\operatorname{Page}(\mathbf{s})}$

Experimental

Metal Binding Study

Synthesis and Characterization

S3-S6

Figure S1

Figure S2

$\mathrm{X}$-ray Structural Studies

$\begin{array}{ll}\text { DynaFit Analysis } & \text { S7 }\end{array}$

Metal Ion Titration Plots $\quad$ S8

Spectral Data Fitting Plots $\quad$ S9

Data Collection and Refinement $\quad \mathrm{S} 10$

Table 1

Crystallographic Summary Table

S11

NMR Data

Figure S3

Figure S4

Figure S5

Figure S6

Figure S7

Figure S8

Figure S9

Figure S10

Figure S11

Figure S12

Figure S13

Figure S14

Figure S15

Figure S16

Figure S17

Figure S18

Figure S19

Figure S20

Figure S21

Figure S22

Figure S23

Figure S24

Figure S25

Figure S26

Figure S27

Figure S28

${ }^{1} \mathrm{H}$ NMR Spectrum of NaLo

$\mathrm{S} 12$

${ }^{13}$ C NMR Spectrum of NaLO $\quad$ S13

${ }^{1}$ H NMR Spectrum of NiLO $\quad$ S14

${ }^{13}$ C NMR Spectrum of NiLO

${ }^{31}$ P NMR Spectrum of NiLO $\quad$ S16

${ }^{1} \mathrm{H}$ NMR Spectrum of 1C $\quad \mathrm{S} 17$

${ }^{13} \mathrm{C}$ NMR Spectrum of $\mathbf{1 C} \quad$ S18

${ }^{1}$ H NMR Spectrum of HL2 $\quad$ S19

${ }^{13}$ C NMR Spectrum of HL2 $\quad$ S20

${ }^{1} \mathrm{H}$ NMR Spectrum of NaL2 $\quad$ S21

${ }^{13} \mathrm{C}$ NMR Spectrum of NaL2 $\quad$ S22

${ }^{1}$ H NMR Spectrum of NiL2 $\quad$ S23

${ }^{13}$ C NMR Spectrum of NiL2 $\quad$ S24

${ }^{31}$ P NMR Spectrum of NiL2

${ }^{1} \mathrm{H}$ NMR Spectrum of 1D $\quad$ S26

${ }^{13}$ C NMR Spectrum of 1D $\quad$ S27

${ }^{1}$ H NMR Spectrum of HL3 $\quad$ S28

${ }^{13}$ C NMR Spectrum of HL3 $\quad$ S29

${ }^{1}$ H NMR Spectrum of NaL3 $\quad$ S30

${ }^{13}$ C NMR Spectrum of NaL3 $\quad$ S31

${ }^{1}$ H NMR Spectrum of NiL3

${ }^{13}$ C NMR Spectrum of NiL3 $\quad$ S33

${ }^{31} \mathrm{P}$ NMR Spectrum of NiL3 $\quad$ S34

DFQ-COSY Spectrum of NiL3

${ }^{1} \mathrm{H}$ NMR Spectrum of $\mathbf{1 E} \quad$ S36

${ }^{13} \mathrm{C}$ NMR Spectrum of 1E $\quad$ S37 
Figure S29

Figure S30

Figure S31

Figure S32

Figure S33

Figure S34

Figure S35

Figure S36

Figure S37

Figure S38

Figure S39
${ }^{1}$ H NMR Spectrum of HL4 $\quad$ S38

${ }^{13}$ C NMR Spectrum of HL4 $\quad$ S39

${ }^{1} \mathrm{H}$ NMR Spectrum of NaL4 $\quad$ S40

${ }^{13} \mathrm{C}$ NMR Spectrum of NaL4 $\quad$ S41

${ }^{1}$ H NMR Spectrum of NiL4

${ }^{13}$ C NMR Spectrum of NiL4 $\quad$ S43

${ }^{31}$ P NMR Spectrum of NiL4

${ }^{1}$ H NMR Spectrum of Solid Polyethylene $\quad$ S45

${ }^{13}$ C NMR Spectrum of Solid Polyethylene $\quad$ S46

${ }^{1}$ H NMR Spectrum of Amorphous Polyethylene $\quad$ S47

${ }^{13}$ C NMR Spectrum of Amorphous Polyethylene S48

S49 


\section{EXPERIMENTAL}

\section{Synthesis}

Preparation of NaL0. Inside the glovebox, HL1 ( $0.21 \mathrm{~g}, 0.67 \mathrm{mmol}, 1.0$ equiv.) was dissolved

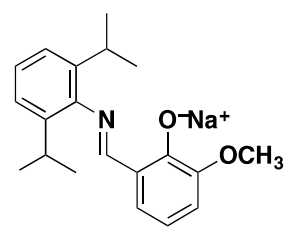
in $10 \mathrm{~mL}$ of THF. Solid $\mathrm{NaH}(60 \%, 0.04 \mathrm{~g}, 1 \mathrm{mmol}, 1.5$ equiv.) was added and the mixture was stirred at room temperature for $2 \mathrm{~h}$. The solution was filtered through a pipet plug to remove a white solid. The yellow filtrate was dried under vacuum and then washed with pentane to give a light yellow solid (0.22 g, $0.66 \mathrm{mmol}, 98 \%) .{ }^{1} \mathrm{H} \mathrm{NMR}\left(\mathrm{CDCl}_{3}, 600 \mathrm{MHz}\right): \delta(\mathrm{ppm})=7.85$ (s, 1H), $6.92(\mathrm{~s}, 3 \mathrm{H}), 6.63(\mathrm{~s}, 1 \mathrm{H}), 6.33(\mathrm{~s}, 1 \mathrm{H}), 6.15(\mathrm{~s}, 1 \mathrm{H}), 2.74(\mathrm{~s}, 3 \mathrm{H}), 2.67(\mathrm{~s}, 2 \mathrm{H}), 0.95$ (s, $6 \mathrm{H}), 0.52(\mathrm{~s}, 6 \mathrm{H}) .{ }^{13} \mathrm{C} \mathrm{NMR}\left(\mathrm{CDCl}_{3}, 150 \mathrm{MHz}\right): \delta(\mathrm{ppm})=167.35,162.93,152.00,150.59$, $138.51,128.18,123.51,123.15,121.10,110.19,109.15,53.93,28.19,25.00,21.83$. ESI-MS(-) calc. for $\mathrm{C}_{20} \mathrm{H}_{25} \mathrm{NO}_{2}[\mathrm{M}-\mathrm{H}]^{-}=310.18130$, found 310.18100 .

Preparation of aldehyde 1C. Solid 2,3-dihydroxybenzaldehyde (1.00 g, 7.25 mmol, 1.0 equiv.)<smiles>COCCOCCOc1cccc(C=O)c1O</smiles>
was dissolved in $25 \mathrm{~mL}$ of DMSO in a Schlenk flask under nitrogen. Small aliquots of $\mathrm{NaH}(60 \%, 0.73 \mathrm{~g}, 18.1 \mathrm{mmol}, 2.5$ equiv.) were added and the mixture was stirred at room temperature with bromoethyl methoxyethyl ether (1.33 g, $7.25 \mathrm{mmol}, 1.0$ equiv.) and then stirred overnight. The reaction was quenched by the addition of $\mathrm{HCl}(\mathrm{aq})$ and was then extracted into $50 \mathrm{~mL}$ of $\mathrm{Et}_{2} \mathrm{O}$. The organic layer was separated, dried over $\mathrm{Na}_{2} \mathrm{SO}_{4}$, filtered, and evaporated to dryness. The crude material was purified by silica gel column chromatography (3:2, hexane:ethyl acetate) to afford a light yellow oil $(0.58 \mathrm{~g}, 2.4 \mathrm{mmol}, 33 \%)$. ${ }^{1} \mathrm{H} \mathrm{NMR}\left(\mathrm{CDCl}_{3}, 400 \mathrm{MHz}\right): \delta(\mathrm{ppm})=$ $10.88(\mathrm{~s}, 1 \mathrm{H}), 9.92(\mathrm{~s}, 1 \mathrm{H}), 7.19\left(\mathrm{dd}, J_{\mathrm{HH}}=6.2 \mathrm{~Hz}, J_{\mathrm{HH}}=1.6 \mathrm{~Hz}, 1 \mathrm{H}\right), 7.15\left(\mathrm{dd}, J_{\mathrm{HH}}=6.4 \mathrm{~Hz}, J_{\mathrm{HH}}=\right.$ $0.8 \mathrm{~Hz}, 1 \mathrm{H}), 6.91\left(\mathrm{t}, J_{\mathrm{HH}}=6.4 \mathrm{~Hz}, 1 \mathrm{H}\right), 4.21\left(\mathrm{t}, J_{\mathrm{HH}}=4.4 \mathrm{~Hz}, 2 \mathrm{H}\right), 3.88\left(\mathrm{t}, J_{\mathrm{HH}}=4.4 \mathrm{~Hz}, 2 \mathrm{H}\right)$, 3.71(m, 2H), $3.55(\mathrm{~m}, 2 \mathrm{H}), 3.36(\mathrm{~s}, 3 \mathrm{H}) .{ }^{13} \mathrm{C} \mathrm{NMR}\left(\mathrm{CDCl}_{3}, 100 \mathrm{MHz}\right): \delta(\mathrm{ppm})=196.24$, 152.15, 147.44, 125.11, 121.25, 120.79, 119.57, 71.96, 70.81, 69.65, 69.29, 59.08. FT-IR: 2876 $\left(v_{\mathrm{CHO}}\right), 1654\left(v_{\mathrm{CO}}\right) \mathrm{cm}^{-1}$. GC-MS calc. for $\mathrm{C}_{12} \mathrm{H}_{16} \mathrm{O}_{5}[\mathrm{M}]^{+}=240.1$, found 240.1 .

Preparation of HL2. Compound 1C (0.45 g, $1.88 \mathrm{mmol}, 1.0$ equiv. $)$ and 2,6-diisopropylaniline

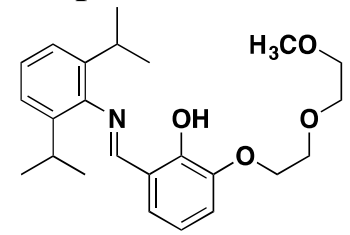
$(0.33 \mathrm{~g}, 1.88 \mathrm{mmol}, 1.0$ equiv.) were dissolved in $5 \mathrm{~mL}$ of $\mathrm{MeOH}$. The mixture was treated with 5 drops of acetic acid and then stirred under reflux for $8 \mathrm{~h}$. The resulting clear yellow solution was evaporated to dryness to yield a yellow oil $(0.55 \mathrm{~g}, 1.38 \mathrm{mmol}, \sim 74 \%)$. This crude product was used in the preparation of NaL2 without further purification.

Pure HL2 can be obtained by purification by silica gel column chromatography (1:1 hexane:ethyl acetate). ${ }^{1} \mathrm{H} \mathrm{NMR}\left(\mathrm{CDCl}_{3}, 600 \mathrm{MHz}\right): \delta(\mathrm{ppm})=13.43(\mathrm{~s}, 1 \mathrm{H}), 8.29(\mathrm{~s}, 1 \mathrm{H}), 7.18$ $(\mathrm{m}, 3 \mathrm{H}), 7.08\left(\mathrm{~d}, J_{\mathrm{HH}}=8.4 \mathrm{~Hz}, 1 \mathrm{H}\right), 6.99\left(\mathrm{~d}, J_{\mathrm{HH}}=6.6 \mathrm{~Hz}, 1 \mathrm{H}\right), 6.88\left(\mathrm{t}, J_{\mathrm{HH}}=7.2 \mathrm{~Hz}, 1 \mathrm{H}\right), 4.28(\mathrm{t}$, $\left.J_{\mathrm{HH}}=5.4 \mathrm{~Hz}, 2 \mathrm{H}\right), 3.96\left(\mathrm{t}, J_{\mathrm{HH}}=4.8 \mathrm{~Hz}, 2 \mathrm{H}\right), 3.76(\mathrm{~m}, 2 \mathrm{H}), 3.60(\mathrm{~m}, 2 \mathrm{H}), 3.39(\mathrm{~s}, 3 \mathrm{H}), 3.00(\mathrm{~m}$, $2 \mathrm{H}), 1.16\left(\mathrm{~d}, J_{\mathrm{HH}}=6.6 \mathrm{~Hz}, 12 \mathrm{H}\right) .{ }^{13} \mathrm{C} \mathrm{NMR}\left(\mathrm{CDCl}_{3}, 150 \mathrm{MHz}\right): \delta(\mathrm{ppm})=166.85,151.81$, $147.70,146.10,138.84,125.63,124.40,123.35,118.93,118.66,117.16,72.06,70.92,69.83$, 68.80, 59.19, 28.19, 23.65. FT-IR: $2960\left(v_{\mathrm{CNH}}\right), 1620\left(v_{\mathrm{CN}}\right) \mathrm{cm}^{-1}$. 
Preparation of NaL2. Inside the glovebox, HL2 (5.32 g, $13.3 \mathrm{mmol}, 1.0$ equiv.) was dissolved

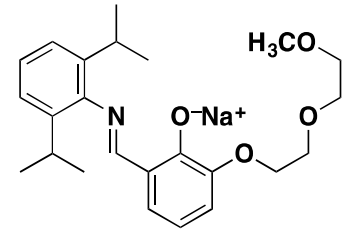
in $100 \mathrm{~mL}$ of THF. Solid $\mathrm{NaH}(60 \%, 1.07 \mathrm{~g}, 26.7 \mathrm{mmol}, 2.0$ equiv.) was added. The mixture was stirred at room temperature for $2 \mathrm{~h}$ and then filtered to remove the insoluble material. The yellow filtrate was collected and the solvent was removed under vacuum. The crude product was washed with pentane and then dried to yield a light yellow solid (4.03 g, $9.5 \mathrm{mmol}, 72 \%) .{ }^{1} \mathrm{H} \mathrm{NMR}\left(\mathrm{CDCl}_{3}, 400 \mathrm{MHz}\right): \delta(\mathrm{ppm})=8.07(\mathrm{~s}, 1 \mathrm{H}), 7.13\left(\mathrm{~d}, J_{\mathrm{HH}}=6 \mathrm{~Hz}, 2 \mathrm{H}\right)$, $7.06\left(\mathrm{t}, J_{\mathrm{HH}}=6 \mathrm{~Hz}, 1 \mathrm{H}\right), 6.95\left(\mathrm{~d}, J_{\mathrm{HH}}=5.2 \mathrm{~Hz}, 1 \mathrm{H}\right), 6.71\left(\mathrm{~d}, J_{\mathrm{HH}}=6 \mathrm{~Hz}, 1 \mathrm{H}\right), 6.15\left(\mathrm{t}, J_{\mathrm{HH}}=6 \mathrm{~Hz}\right.$, $1 \mathrm{H}), 3.88(\mathrm{~s}, 2 \mathrm{H}), 3.33-3.27(\mathrm{~m}, 9 \mathrm{H}), 3.07(\mathrm{~m}, 2 \mathrm{H}), 1.13\left(\mathrm{~d}, J_{\mathrm{HH}}=4.8 \mathrm{~Hz}, 12 \mathrm{H}\right) .{ }^{13} \mathrm{C} \mathrm{NMR}$ $\left(\mathrm{CDCl}_{3}, 100 \mathrm{MHz}\right): \delta(\mathrm{ppm})=166.39,165.30,152.00,151.17,139.18,128.63,123.28,122.77$, $122.09,115.75,106.76,70.67,68.10,67.84,66.94,65.98,58.93,27.70,24.15,15.40$. ESI-MS() calc. for $\mathrm{C}_{24} \mathrm{H}_{32} \mathrm{NO}_{4}[\mathrm{M}-\mathrm{H}]^{-}=398.23370$, found 398.23380 .

Preparation of aldehyde 1D. Solid 2,3-dihydroxybenzaldehyde (2.3 g, 16 mmol, 1.0 equiv.)

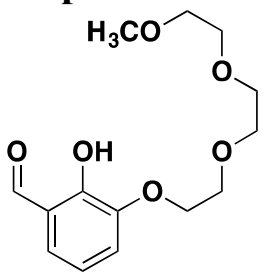
was dissolved in $50 \mathrm{~mL}$ of DMSO in a Schlenk flask under nitrogen. Small aliquots of $\mathrm{NaH}(60 \%, 1.6 \mathrm{~g}, 41 \mathrm{mmol}, 2.5$ equiv.) were added and the mixture was stirred at room temperature for $2 \mathrm{~h}$. The resulting dark red solution was treated with triethylene glycol methyl $p$-tosyl ether $(5.2 \mathrm{~g}, 16 \mathrm{mmol}, 1.0$ equiv.) and then stirred overnight. The reaction was quenched by the addition of $\mathrm{HCl}$ (aq) and was then extracted into $50 \mathrm{~mL}$ of $\mathrm{Et}_{2} \mathrm{O}$. The organic layer was separated, dried over $\mathrm{Na}_{2} \mathrm{SO}_{4}$, filtered, and evaporated to dryness. The crude material was purified by silica gel column chromatography ( $3: 2$, toluene:ethyl acetate) to afford a light yellow oil (2.6 g, $9.2 \mathrm{mmol}, 55 \%) .{ }^{1} \mathrm{H}$ NMR $\left(\mathrm{CDCl}_{3}, 600 \mathrm{MHz}\right): \delta(\mathrm{ppm})=10.88(\mathrm{~s}, 1 \mathrm{H}), 9.95(\mathrm{~s}, 1 \mathrm{H})$, $7.21\left(\mathrm{~d}, J_{\mathrm{HH}}=8.4 \mathrm{~Hz}, 1 \mathrm{H}\right), 7.17\left(\mathrm{~d}, J_{\mathrm{HH}}=7.8 \mathrm{~Hz}, 1 \mathrm{H}\right), 6.92\left(\mathrm{t}, J_{\mathrm{HH}}=8.4 \mathrm{~Hz}, 1 \mathrm{H}\right), 4.21 \quad\left(\mathrm{t}, J_{\mathrm{HH}}=5.4\right.$ $\mathrm{Hz}, 2 \mathrm{H}), 3.89$ (t, $\left.J_{\mathrm{HH}}=4.8 \mathrm{~Hz}, 2 \mathrm{H}\right), 3.73(\mathrm{~m}, 2 \mathrm{H}), 3.67(\mathrm{~m}, 2 \mathrm{H}), 3.64(\mathrm{~m}, 2 \mathrm{H}), 3.55(\mathrm{~m}, 2 \mathrm{H}), 3.36$ $(\mathrm{s}, 3 \mathrm{H}) .{ }^{13} \mathrm{C} \mathrm{NMR}\left(\mathrm{CDCl}_{3}, 150 \mathrm{MHz}\right): \delta(\mathrm{ppm})=195.29,151.93,147.32,124.09,121.59$, 120.12, 119.37, 71.80, 70.66, 70.73, 70.29, 69.46, 68.83, 58.82. FT-IR: 2871 ( $\left.v_{\mathrm{CHO}}\right), 1654\left(v_{\mathrm{CO}}\right)$ $\mathrm{cm}^{-1}$. GC-MS calc. for $\mathrm{C}_{14} \mathrm{H}_{20} \mathrm{O}_{6}[\mathrm{M}]^{+}=284.1$, found 284.1 .

Preparation of HL3. Compound 1D ( $0.71 \mathrm{~g}, 2.5 \mathrm{mmol}, 1.0$ equiv.) and 2,6-diisopropylaniline

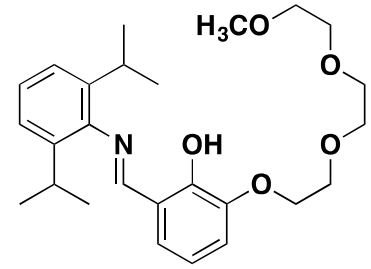
( $0.44 \mathrm{~g}, 2.5 \mathrm{mmol}, 1.0$ equiv.) were dissolved in $10 \mathrm{~mL}$ of $\mathrm{MeOH}$. The mixture was treated with 5 drops of acetic acid and then stirred under reflux for $8 \mathrm{~h}$. The resulting clear yellow solution was evaporated to dryness to yield a yellow oil (1.0 g, $2.4 \mathrm{mmol}, \sim 95 \%)$. This crude product was used in the preparation of NaL3 without further purification. Pure HL3 can be obtained by purification by silica gel column chromatography $\left(1: 1\right.$, hexane:ethyl acetate). ${ }^{1} \mathrm{H} \mathrm{NMR}\left(\mathrm{CDCl}_{3}, 600 \mathrm{MHz}\right): \delta(\mathrm{ppm})=13.42(\mathrm{~s}$, $1 \mathrm{H}), 8.29(\mathrm{~s}, 1 \mathrm{H}), 7.17(\mathrm{~m}, 3 \mathrm{H}), 7.07\left(\mathrm{~d}, J_{\mathrm{HH}}=7.8 \mathrm{~Hz}, 1 \mathrm{H}\right), 6.99\left(\mathrm{~d}, J_{\mathrm{HH}}=7.8 \mathrm{~Hz}, 1 \mathrm{H}\right), 6.88(\mathrm{t}$, $\left.J_{\mathrm{HH}}=8.4 \mathrm{~Hz}, 1 \mathrm{H}\right), 4.26\left(\mathrm{t}, J_{\mathrm{HH}}=4.8 \mathrm{~Hz}, 2 \mathrm{H}\right), 3.94\left(\mathrm{t}, J_{\mathrm{HH}}=4.8 \mathrm{~Hz}, 2 \mathrm{H}\right), 3.77\left(\mathrm{t}, J_{\mathrm{HH}}=4.8 \mathrm{~Hz}, 2 \mathrm{H}\right)$, $3.69\left(\mathrm{t}, J_{\mathrm{HH}}=4.8 \mathrm{~Hz} 2 \mathrm{H}\right), 3.66\left(\mathrm{t}, J_{\mathrm{HH}}=3.6 \mathrm{~Hz}, 2 \mathrm{H}\right), 3.54\left(\mathrm{t}, J_{\mathrm{HH}}=4.8 \mathrm{~Hz}, 2 \mathrm{H}\right), 3.37(\mathrm{~s}, 3 \mathrm{H}) 2.98$ $(\mathrm{m}, 2 \mathrm{H}), 1.16\left(\mathrm{~d}, J_{\mathrm{HH}}=7.2 \mathrm{~Hz}, 12 \mathrm{H}\right) .{ }^{13} \mathrm{C} \mathrm{NMR}\left(\mathrm{CDCl}_{3}, 150 \mathrm{MHz}\right): \delta(\mathrm{ppm})=166.84,151.85$, $147.71,146.09,138.84,125.63,124.41,123.34,118.93,118.65,117.26,72.03,70.98,70.75$, 70.64, 69.81, 68.82, 59.13, 28.19, 23.64. FT-IR: $2960\left(v_{\mathrm{CHN}}\right), 1619\left(v_{\mathrm{CN}}\right) \mathrm{cm}^{-1}$. 
Preparation of NaL3. Inside the glovebox, HL3 (1.4 g, $3.1 \mathrm{mmol}, 1.0$ equiv.) was dissolved in

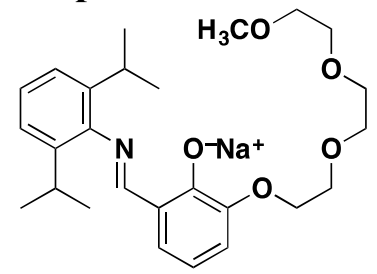
$20 \mathrm{~mL}$ of THF. Solid $\mathrm{NaH}(60 \%, 0.19 \mathrm{~g}, 4.7 \mathrm{mmol}, 1.5$ equiv.) was added. The mixture was stirred at room temperature for $2 \mathrm{~h}$ and then filtered to remove the insoluble material. The yellow filtrate was collected and the solvent was removed under vacuum. The crude product was washed with pentane and then dried to yield a light yellow solid (1.08 g, $2.3 \mathrm{mmol}, 74 \%) .{ }^{1} \mathrm{H} \mathrm{NMR}\left(\mathrm{CDCl}_{3}, 600 \mathrm{MHz}\right): \delta(\mathrm{ppm})=8.76(\mathrm{~s}$, $1 \mathrm{H}), 7.68\left(\mathrm{~d}, J_{\mathrm{HH}}=6.6 \mathrm{~Hz}, 1 \mathrm{H}\right), 7.06\left(\mathrm{~d}, J_{\mathrm{HH}}=7.2 \mathrm{~Hz}, 2 \mathrm{H}\right), 6.97\left(\mathrm{t}, J_{\mathrm{HH}}=7.2 \mathrm{~Hz}, 1 \mathrm{H}\right), 6.64(\mathrm{~d}$ $\left.J_{\mathrm{HH}}=7.8 \mathrm{~Hz}, 1 \mathrm{H}\right), 6.23\left(\mathrm{t}, J_{\mathrm{HH}}=7.8 \mathrm{~Hz}, 1 \mathrm{H}\right), 3.95\left(\mathrm{t}, J_{\mathrm{HH}}=4.2 \mathrm{~Hz}, 2 \mathrm{H}\right), 3.60(\mathrm{~s}, 2 \mathrm{H}), 3.28-3.20$ $(\mathrm{m}, 11 \mathrm{H}), 3.09(\mathrm{~m}, 2 \mathrm{H}), 1.13\left(\mathrm{~d}, J_{\mathrm{HH}}=6.6 \mathrm{~Hz}, 12 \mathrm{H}\right) .{ }^{13} \mathrm{C} \mathrm{NMR}\left(\mathrm{CDCl}_{3}, 150 \mathrm{MHz}\right): \delta(\mathrm{ppm})=$ 165.02, 161.61, 152.03, 151.54, 138.28, 123,47, 122.58, 122.41, 120.46, 111.72, 107.83, 70.18, $69.31,68.80,68.50,68.22,65.65,59.05,27.78,23.44$. ESI-MS(-) calc for $\mathrm{C}_{26} \mathrm{H}_{36} \mathrm{NO}_{5}[\mathrm{M}-\mathrm{H}]^{-}=$ 442.25990, found 442.26030.

Preparation of aldehyde 1E. Solid 2,3-dihydroxybenzaldehyde (1.1 g, $8.3 \mathrm{mmol}, 1.0$ equiv.)

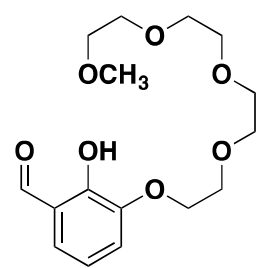
was dissolved in $20 \mathrm{~mL}$ of DMSO in a Schlenk flask under nitrogen. Small aliquots of $\mathrm{NaH}(60 \%, 828 \mathrm{mg}, 21 \mathrm{mmol}, 2.5$ equiv.) were added and the mixture was stirred at room temperature for $2 \mathrm{~h}$. The resulting dark red solution was treated with tetraethylene glycol methyl $p$-tosyl ether $(3.09 \mathrm{~g}, 8.3 \mathrm{mmol}$, 1.0 equiv.) and then stirred overnight. The reaction was quenched by the addition of $\mathrm{HCl}(\mathrm{aq})$ and was then extracted into $50 \mathrm{~mL}$ of $\mathrm{Et}_{2} \mathrm{O}$. The organic layer was separated, dried over $\mathrm{Na}_{2} \mathrm{SO}_{4}$, filtered, and evaporated to dryness.

The crude material was purified by silica gel column chromatography (1:1 hexane:ethyl acetate to 1:4 hexane: ethyl acetate) to afford a light yellow oil $(1.1 \mathrm{~g}, 3.2 \mathrm{mmol}, 39 \%)$. ${ }^{1} \mathrm{H} \mathrm{NMR}$ $\left(\mathrm{CDCl}_{3}, 500 \mathrm{MHz}\right): \delta(\mathrm{ppm})=10.82(\mathrm{~s}, 1 \mathrm{H}), 9.91(\mathrm{~s}, 1 \mathrm{H}), 7.17\left(\mathrm{dd}, J_{\mathrm{HH}}=7.5 \mathrm{~Hz}, J_{\mathrm{HH}}=1.0 \mathrm{~Hz}\right.$, $1 \mathrm{H}), 7.12\left(\mathrm{dd}, J_{\mathrm{HH}}=8.0 \mathrm{~Hz}, J_{\mathrm{HH}}=1.5 \mathrm{~Hz}, 1 \mathrm{H}\right), 6.88\left(\mathrm{t}, J_{\mathrm{HH}}=7.5 \mathrm{~Hz}, 1 \mathrm{H}\right), 4.17\left(\mathrm{t}, J_{\mathrm{HH}}=4.5 \mathrm{~Hz}\right.$, 2H), $3.84(\mathrm{~m}, 2 \mathrm{H}), 3.69(\mathrm{~m}, 2 \mathrm{H}), 3.64-3.58(\mathrm{~m}, 8 \mathrm{H}), 3.49(\mathrm{~m}, 2 \mathrm{H}), 3.32(\mathrm{~s}, 3 \mathrm{H}) .{ }^{13} \mathrm{C}$ NMR $\left(\mathrm{CDCl}_{3}, 125 \mathrm{MHz}\right): \delta(\mathrm{ppm})=196.11,152.22,147.50,125.04,121.32,120.86,119.55,71.96$, 70.91, 70.65, 70.56, 69.66, 69.32,59.09. FT-IR: $2873\left(v_{\mathrm{CHO}}\right), 1655\left(v_{\mathrm{CO}}\right) \mathrm{cm}^{-1}$. GC-MS calc. for $\mathrm{C}_{16} \mathrm{H}_{24} \mathrm{O}_{7}[\mathrm{M}]^{+}=328.2$, found 328.2 .

Preparation of HL4. Compound 1E (0.43 g, $1.3 \mathrm{mmol}, 1.0$ equiv.) and 2,6-diisopropylaniline

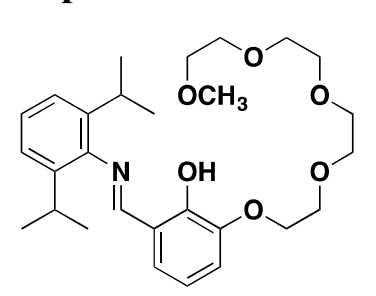
$(0.23 \mathrm{~g}, 1.3 \mathrm{mmol}, 1.0$ equiv.) were dissolved in $10 \mathrm{~mL}$ of $\mathrm{MeOH}$. The mixture was treated with 5 drops of acetic acid and then stirred under reflux for $8 \mathrm{~h}$. The resulting clear yellow solution was evaporated to dryness to yield a yellow oil $(0.63 \mathrm{~g}, 1.3 \mathrm{mmol}, 100 \%)$. This crude product was used in the preparation of NaL4 without further purification. Pure HL4 can be obtained by purification by silica gel column chromatography $\left(1: 1\right.$, hexane:ethyl acetate). ${ }^{1} \mathrm{H} \mathrm{NMR}\left(\mathrm{CDCl}_{3}, 600\right.$ $\mathrm{MHz}): \delta(\mathrm{ppm})=13.38(\mathrm{~s}, 1 \mathrm{H}), 8.27,(\mathrm{~s}, 1 \mathrm{H}), 7.14(\mathrm{~m}, 3 \mathrm{H}), 7.05\left(\mathrm{~d}, J_{\mathrm{HH}}=8.4 \mathrm{~Hz}, 1 \mathrm{H}\right), 6.97(\mathrm{~d}$, $\left.J_{\mathrm{HH}}=7.2 \mathrm{~Hz}, 1 \mathrm{H}\right), 6.85\left(\mathrm{t}, J_{\mathrm{HH}}=8.4 \mathrm{~Hz}, 1 \mathrm{H}\right), 4.24\left(\mathrm{t}, J_{\mathrm{HH}}=4.8 \mathrm{~Hz}, 2 \mathrm{H}\right), 3.92\left(\mathrm{t}, J_{\mathrm{HH}}=4.8 \mathrm{~Hz}, 2 \mathrm{H}\right)$, $3.75(\mathrm{~m}, 2 \mathrm{H}), 3.67-3.60(\mathrm{~m}, 8 \mathrm{H}), 3.50(\mathrm{~m}, 2 \mathrm{H}), 3.32(\mathrm{~s}, 3 \mathrm{H}), 2.97(\mathrm{~m}, 2 \mathrm{H}), 1.13\left(\mathrm{~d}, J_{\mathrm{HH}}=6.6 \mathrm{~Hz}\right.$, $12 \mathrm{H}) .{ }^{13} \mathrm{C} \mathrm{NMR}\left(\mathrm{CDCl}_{3}, 150 \mathrm{MHz}\right): \delta(\mathrm{ppm})=166.84,151.83,147.70,146.12,138.76,125.63$, 124.41, 123.32, 118.94, 118.68,117.30, 72.00, 70.97, 70.69, 70.58, 69.81, 68.85, 59.07, 28.18, 23.64. FT-IR: $2869\left(v_{\mathrm{CHN}}\right), 1620\left(v_{\mathrm{CN}}\right) \mathrm{cm}^{-1}$. 
Preparation of NaL4. Inside the glovebox, HL4 ( $0.60 \mathrm{~g}, 1.2 \mathrm{mmol}, 1.0$ equiv.) was dissolved in<smiles>COCCCCOCCOCCOc1cccc(/C=C/c2c(C(C)C)cccc2C(C)C)c1OC</smiles>
$10 \mathrm{~mL}$ of THF. Solid $\mathrm{NaH}(60 \%, 74 \mathrm{mg}, 1.8 \mathrm{mmol}, 1.5$ equiv.) was added. The mixture was stirred at room temperature for $2 \mathrm{~h}$ and then filtered to remove the insoluble material. The yellow filtrate was collected and the solvent was removed under vacuum. The crude product was washed with pentane and then dried to yield a light yellow solid $(0.600 \mathrm{~g}, 1.18 \mathrm{mmol}, 96 \%) .{ }^{1} \mathrm{H} \mathrm{NMR}\left(\mathrm{CDCl}_{3}, 600 \mathrm{MHz}\right): \delta(\mathrm{ppm})=$ $8.72(\mathrm{~s}, 1 \mathrm{H}), 7.62(\mathrm{~s}, 1 \mathrm{H}), 7.07\left(\mathrm{~d}, J_{\mathrm{HH}}=7.8 \mathrm{~Hz}, 2 \mathrm{H}\right), 6.97\left(\mathrm{t}, J_{\mathrm{HH}}=7.2 \mathrm{~Hz}, 1 \mathrm{H}\right), 6.68\left(\mathrm{~d}, J_{\mathrm{HH}}=\right.$ $6.6 \mathrm{~Hz}, 1 \mathrm{H}), 6.20\left(\mathrm{t}, J_{\mathrm{HH}}=7.8 \mathrm{~Hz}, 1 \mathrm{H}\right), 3.98(\mathrm{~s}, 2 \mathrm{H}), 3.65(\mathrm{~s}, 2 \mathrm{H}), 3.50(\mathrm{~s}, 2 \mathrm{H}), 3.44(\mathrm{~s}, 2 \mathrm{H}), 3.39-$ $3.34(\mathrm{~m}, 8 \mathrm{H}), 3.09(\mathrm{~m}, 2 \mathrm{H}), 3.01(\mathrm{~s}, 3 \mathrm{H}), 1.13\left(\mathrm{~d}, J_{\mathrm{HH}}=6.6 \mathrm{~Hz}, 12 \mathrm{H}\right) .{ }^{13} \mathrm{C} \mathrm{NMR}\left(\mathrm{CDCl}_{3}, 100\right.$ $\mathrm{MHz}): \delta(\mathrm{ppm})=165.40,162.08,152.16,151.50,138.30,123.67,122.85,122.68,122.46$, $113.47,107.82,71.40,69.69,69.04,69.02,68.81,68.62,68.47,66.46,58.80,27.81,23.52$, 22.56. ESI-MS(-) calc. for $\mathrm{C}_{28} \mathrm{H}_{40} \mathrm{NO}_{6}[\mathrm{M}-\mathrm{H}]^{-}=486.28610$, found 486.28650 .

Preparation of $\operatorname{LiBAr}^{\mathbf{F}}$. A $20 \mathrm{~mL}$ solution of 3,5-bis(trifluoromethyl)bromobenzene (2.0 g, 6.8

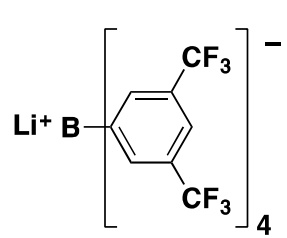
mmol, 5 equiv.) in dry $\mathrm{Et}_{2} \mathrm{O}$ was added slowly using an addition funnel to a Schlenk flask containing magnesium turnings $(0.20 \mathrm{~g}, 8.2 \mathrm{mmol}, 6.2$ equiv. $)$ in $15 \mathrm{~mL}$ of $\mathrm{Et}_{2} \mathrm{O}$. The mixture was stirred under reflux for 30 min to give a light brown solution. Solid $\mathrm{LiBF}_{4}(0.13 \mathrm{~g}, 1.4 \mathrm{mmol}, 1$ equiv.) was added and the reaction was stirred at $\mathrm{RT}$ for an additional $48 \mathrm{~h}$. About $\sim 15 \mathrm{~mL}$ of $1,4-$ dioxane was added, which led to precipitation of a large amount of magnesium dihalide. The solvent was removed under vacuum and the reaction flask was brought inside the glovebox for further workup. Inside the glovebox, the product was extracted into $\mathrm{Et}_{2} \mathrm{O}$ and the insoluble material was removed by filtration through a glass frit. The filtrate was evaporated to dryness and the resulting solid was re-dissolved in a minimal amount of $\mathrm{Et}_{2} \mathrm{O}$ and then layered with pentane. Upon storing at $-30^{\circ} \mathrm{C}$ overnight, a large amount of colorless crystals had formed. The crystals were isolated by filtration and dried to afford a white solid $(0.74 \mathrm{~g}, 0.85$ mmol, 63\%). The NMR spectra of this material were identical to those reported previously. ${ }^{1}$ 


\section{Metal Binding Study}

The dilution-corrected spectra obtained from the addition of alkali salts $\left(\mathrm{M}^{+}\right)$to solutions of the NiL complexes are shown in Figure S1. The program DynaFit ${ }^{2}$ was used for non-linear regression fitting of the titration data based on absorbance changes observed at $340 \mathrm{~nm}$. The data were fit to two different binding models, where one model assumes the formation of 1:1 NiL: $\mathrm{M}^{+}$ species and the second assumes the formation of a mixture of $1: 1$ and $2: 1 \mathrm{NiL}: \mathrm{M}^{+}$species. In almost in all cases, the latter model gave a better fit than the former based on statistical error analysis. The only exception is the titration data acquired from the addition of $\mathrm{Na}^{+}$to $\mathbf{N i L 4}$, which gave a better fit using a 1:1 rather than a 1:1/2:1 binding model. The Dynafit scripts for the two models used are provided below. Parameters that are allowed to vary in the fitting process are marked with “?” and all other parameters were held fixed.

\section{A) 1:1 stoichiometry}

[task]

task $=$ fit

data $=$ equilibria

[mechanism]

$\mathrm{Ni}+\mathrm{M}<==>\mathrm{NiM}: \mathrm{K} 1$ association

[constants]

$\mathrm{K} 1=.01$ ?

[concentrations]

$\mathrm{Ni}=100$

[responses]

$\mathrm{Ni}=0.003 ?$

$\mathrm{NiM}=0.001$ ?

[data]

variable $\mathrm{M}$

file./Experiments/data.txt

[output]

directory ./Experiments/output/data

[end]

\section{B) 1:1 and 2:1 stoichiometry}

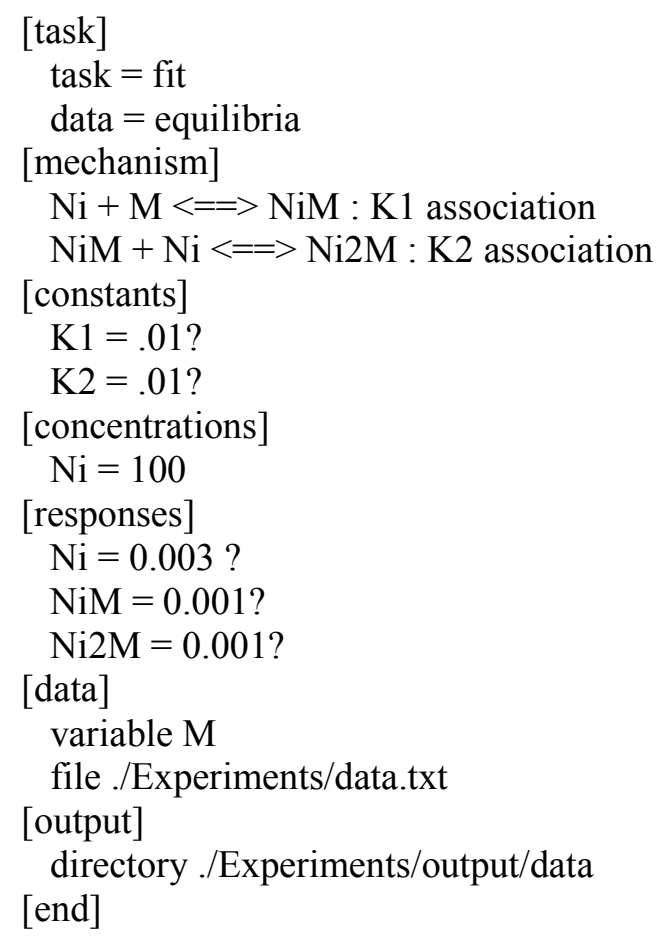



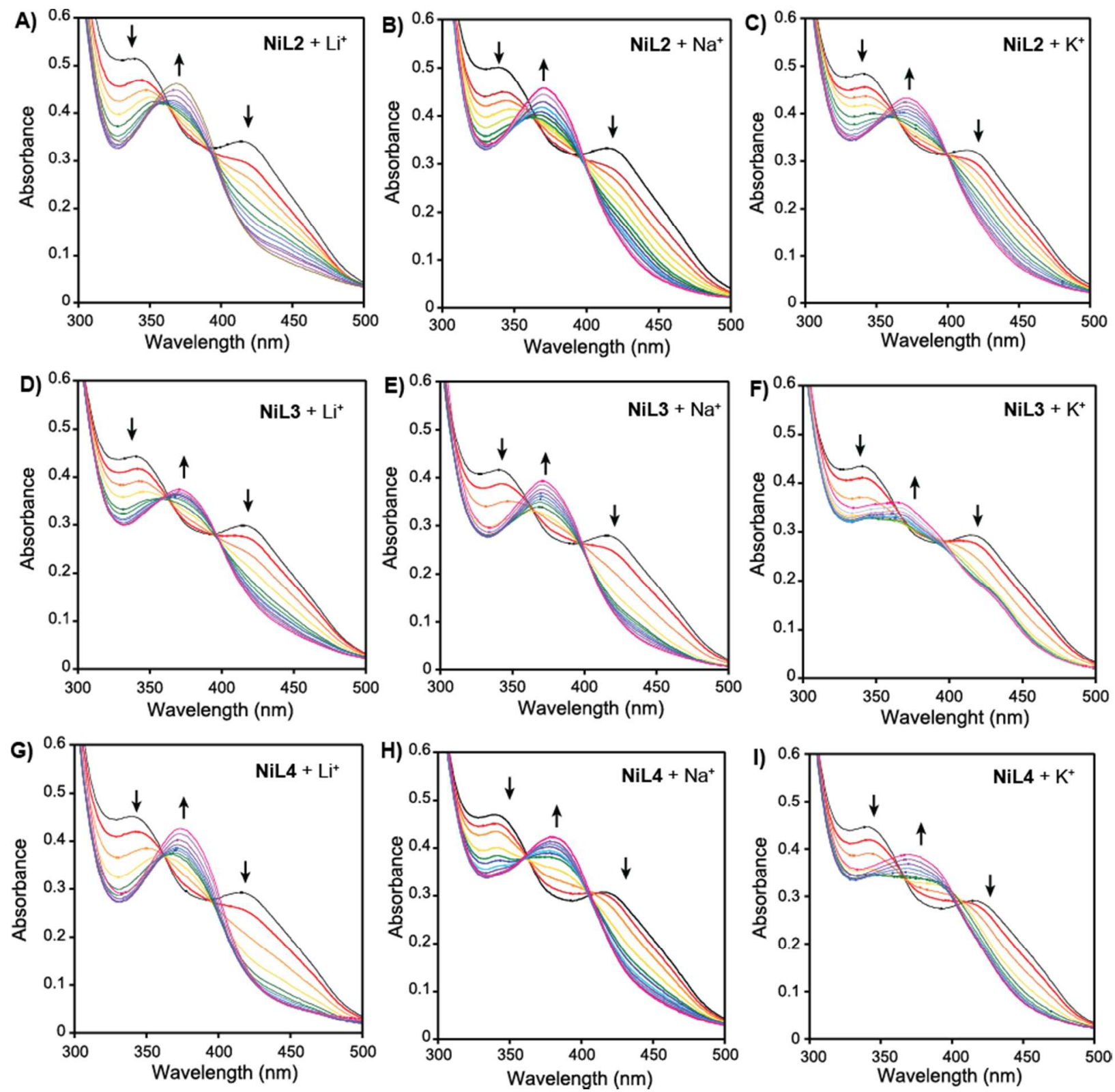

Figure S1. UV-vis spectral changes observed from the addition of $\mathrm{MBAr}_{4}^{\mathrm{F}}\left(\mathrm{M}^{+}=\mathrm{Li}^{+}, \mathrm{Na}^{+}\right.$, and $\left.\mathrm{K}^{+}\right)$to solutions of $\mathrm{NiL}\left(100 \mu \mathrm{M}\right.$ in $\left.\mathrm{Et}_{2} \mathrm{O}\right)$. Small aliquots containing 0.1 equiv. of $\mathrm{M}^{+}$, relative to NiL, were added to NiL and the solutions were allowed to equilibrate for 20-30 min before recording the spectra. The titration plots are shown for the following: A) $\mathbf{N i L 2} / \mathrm{Li}^{+}$, B) $\mathbf{N i L 2} / \mathrm{Na}^{+}$, C) $\mathbf{N i L 2} / \mathrm{K}^{+}$, D) $\mathbf{N i L 3} / \mathrm{Li}^{+}$, E) $\mathbf{N i L 3} / \mathrm{Na}^{+}$, F) $\mathbf{N i L 3} / \mathrm{K}^{+}$, G) $\left.\mathbf{N i L 4} / \mathrm{Li}^{+}, \mathrm{H}\right) \mathbf{N i L 4} / \mathrm{Na}^{+}$, and I) $\mathrm{NiL2} / \mathrm{K}^{+}$. The data have been corrected for dilution. 

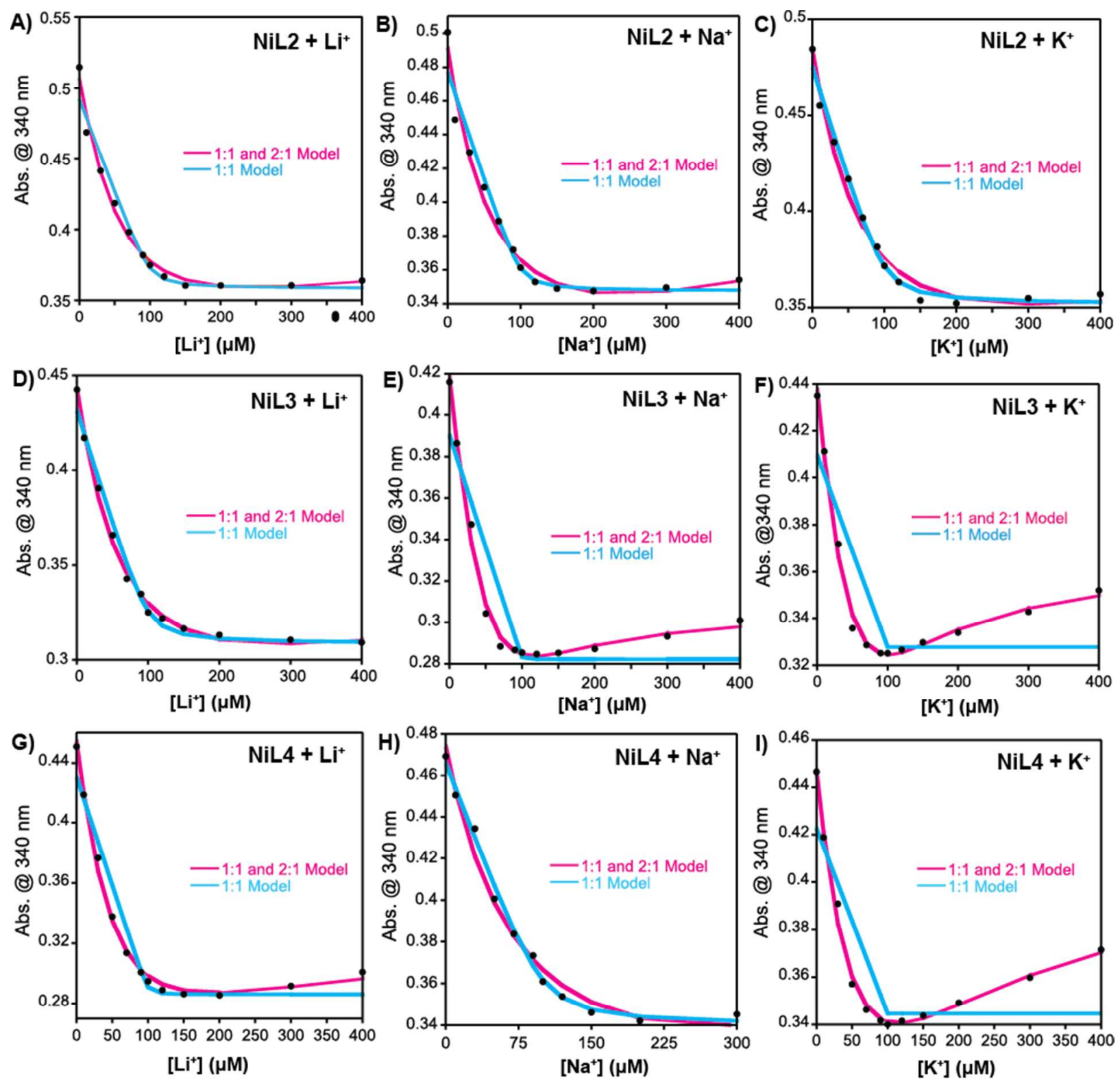

Figure S2. The single-wavelength absorption changes at $340 \mathrm{~nm}$ observed from the metal titration studies shown in Figure S1. The experimental data are shown as black dots. The data were fit to two metal binding models: the magenta trace represents a 1:1 and 2:1 NiL: $\mathrm{M}^{+}$model whereas the blue trace represents a 1:1 NiL:M model. In almost all cases, except for $\mathbf{N i L 4} / \mathrm{Na}^{+}$, the 1:1 and 2:1 model fits the data better than the 1:1 model. The binding constants $K_{a 1}$ and $K_{a 2}$ derived from data fitting are provided in Table 1. The single-wavelength titration plots are shown for: A) $\mathbf{N i L 2} / \mathrm{Li}^{+}$, B) $\mathbf{N i L 2} / \mathrm{Na}^{+}$, C) $\mathbf{N i L 2} / \mathrm{K}^{+}$, D) $\mathbf{N i L 3} / \mathrm{Li}^{+}$, E) $\mathbf{N i L 3} / \mathrm{Na}^{+}$, F) $\mathbf{N i L 3} / \mathrm{K}^{+}, \mathrm{G}$ ) $\left.\mathrm{NiL4} / \mathrm{Li}^{+}, \mathrm{H}\right) \mathrm{NiL4} / \mathrm{Na}^{+}$, and I) $\mathrm{NiL} 2 / \mathrm{K}^{+}$. 


\section{X-ray Data Collection and Refinement}

Single crystals suitable for X-ray diffraction studies were picked out of the crystallization vials and mounted onto Mitogen loops using Paratone oil. The crystals of NiL2 $2_{\text {Mes, NiNaL3, and }}$ NiKL4 were collected at a $6.0 \mathrm{~cm}$ detector distance ( $40 \mathrm{~s} /$ frame exposure time), whereas that of $\mathbf{N i}_{2} \mathbf{N a L 2} 2_{2}$ was collected at a $9.0 \mathrm{~cm}$ detector distance $(60 \mathrm{~s} /$ frame exposure time) to prevent diffraction spot overlap due to its large cell size $(\mathrm{a}=12.0 \AA, b=59.9 \AA, c=17.3 \AA)$. The structure of NiL2 $2_{\text {Mes }}$ contains a pentane solvent molecule that is located on an inversion center, which was refined in Part -1 to suppress the generation of special position constraints and by using a site occupancy factor (sof) of 10.5000. Four of the $\mathrm{CF}_{3}$ groups in the $\mathrm{BAr}_{4}{ }_{4}^{-}$anion show significant rotational disorder and were refined separately as a two-part disorder using independent variables. The fluorine atoms of the disordered $\mathrm{CF}_{3}$ groups were fixed to have equal atomic displacement parameters. The structure of $\mathbf{N i}_{2} \mathbf{N a L 2} \mathbf{2}_{2}$ has several severely disordered phenyl rings, two of which are attached to $\mathrm{P}(1)$ of a triphenylphosphine ligand. These $\mathrm{C}_{6} \mathrm{H}_{5}$ groups $[\mathrm{C}(79)-\mathrm{C}(84)$ and $\mathrm{C}(85)-\mathrm{C}(90)]$ were modeled as two-part positional disorders. The phenyl group [C(73)- $\mathrm{C}(77)]$ that is coordinated to $\mathrm{Ni}(1)$ was refined using an AFIX 66 rigid group constraint and its carbon atoms were given equal atomic displacement parameters. The elongated ADPs of the $\mathrm{C}(73)-\mathrm{C}(77)$ atoms suggest that this group is also disordered, but attempts to model the disorder did not give a stable structure refinement. Four of the $\mathrm{CF}_{3}$ groups in the $\mathrm{BAr}_{4}{ }^{-}$anion were also modeled as positional disorders using independent variables. The crystal structures of NiNaL3 and NiKL4 both contain $\mathrm{BAr}_{4}^{\mathrm{F}}{ }_{-}^{-}$anions with several disordered $\mathrm{CF}_{3}$ units, which were also refined accordingly. 
Table S1. Crystallographic table for NiL2 $2_{\mathrm{Mes}}, \mathrm{NiNaL3}, \mathrm{NiKL4}$, and $\mathrm{Ni}_{2} \mathrm{NaL2}_{2}$

\begin{tabular}{|c|c|c|c|c|}
\hline & NiL2 ${ }_{\text {Mes }} \cdot\left(\mathrm{C}_{5} \mathrm{H}_{12}\right)$ & $\mathbf{N i N a L 3} \cdot\left(\mathrm{C}_{5} \mathrm{H}_{12}\right)_{0.5}$ & NiKL4 & $\mathrm{Ni}_{2} \mathrm{NaL2}_{2}$ \\
\hline Empirical Formula & $\mathrm{NiC}_{51} \mathrm{H}_{58} \mathrm{NO}_{4} \mathrm{P} \cdot\left(\mathrm{C}_{5} \mathrm{H}_{12}\right)$ & $\begin{array}{l}\mathrm{NiNaC}_{82} \mathrm{H}_{68} \mathrm{NO}_{5} \mathrm{PBF}_{24} \\
\cdot\left(\mathrm{C}_{5} \mathrm{H}_{12}\right)_{0.5}\end{array}$ & $\mathrm{NiKC}_{84} \mathrm{H}_{72} \mathrm{NO}_{6} \mathrm{PBF}_{24}$ & $\begin{array}{l}\mathrm{Ni}_{2} \mathrm{NaC}_{128} \mathrm{H}_{118} \mathrm{~N}_{2} \mathrm{O}_{8} \mathrm{P}_{2} \mathrm{~B} \\
\mathrm{~F}_{24}\end{array}$ \\
\hline Formula Weight & 838.66 & 1762.93 & 1787.02 & 2481.40 \\
\hline Temperature $\left({ }^{\circ} \mathrm{C}\right)$ & -150 & -150 & -150 & -150 \\
\hline Wavelength $(\AA)$ & 0.71073 & 0.71073 & 0.71073 & 0.71073 \\
\hline Crystal System, & Orthorhombic, & Triclinic, & Triclinic, & Monoclinic, \\
\hline Space Group & $\mathrm{Pna}_{1}$ & $\mathrm{P} \overline{1}$ & $\mathrm{P} \overline{1}$ & $\mathrm{P} 2{ }_{1} / \mathrm{c}$ \\
\hline \multicolumn{5}{|l|}{ Unit Cell Dimensions } \\
\hline$a(\AA)$ & $24.3130(12)$ & $12.161(4)$ & $11.539(3)$ & $12.0736(10)$ \\
\hline$b(\AA)$ & $9.2770(5)$ & $18.240(6)$ & $19.626(4)$ & $59.562(5)$ \\
\hline$c(\AA)$ & $19.2048(11)$ & $18.943(6)$ & $21.139(5)$ & $17.2666(14)$ \\
\hline$\alpha\left(^{\circ}\right)$ & & $85.263(4)$ & $62.823(2)$ & \\
\hline$\beta\left(^{\circ}\right)$ & & $80.079(4)$ & $78.790(3)$ & $101.397(4)$ \\
\hline$\gamma\left({ }^{\circ}\right)$ & & $86.325(4)$ & $88.281(3)$ & \\
\hline Volume $\left(\AA^{3}\right)$ & $4331.7(4)$ & $4119(2)$ & $4167.9(15)$ & $12172.1(17)$ \\
\hline Z, Calculated Density $\left(\mathrm{Mg} / \mathrm{m}^{3}\right)$ & $4,1.286$ & $2,1.421$ & $2,1.424$ & $4,1.354$ \\
\hline Absorption Coefficient $\left(\mathrm{mm}^{-1}\right)$ & 0.531 & 0.366 & 0.408 & 0.433 \\
\hline $\mathbf{F}(000)$ & 1784 & 1806 & 1828 & 5218 \\
\hline Theta Range for Data Collection $\left(^{\circ}\right)$ & 1.98 to 30.56 & 1.86 to 25.00 & 1.11 to 26.37 & 0.68 to 24.71 \\
\hline \multirow[t]{3}{*}{ Limiting Indices } & $-34 \leq \mathrm{h} \leq 34$ & $-11 \leq \mathrm{h} \leq 16$ & $-14 \leq h \leq 11$ & $-14 \leq h \leq 14$ \\
\hline & $-13 \leq \mathrm{k} \leq 13$ & $-21 \leq \mathrm{k} \leq 24$ & $-15 \leq \mathrm{k} \leq 24$ & $-68 \leq \mathrm{k} \leq 69$ \\
\hline & $-23 \leq 1 \leq 27$ & $-25 \leq 1 \leq 25$ & $-26 \leq 1 \leq 26$ & $-20 \leq 1 \leq 20$ \\
\hline \multirow[t]{2}{*}{ Reflections Collected/ Unique } & $55608 / 12540$ & $24671 / 18618$ & $2270 / 16320$ & $58475 / 19956$ \\
\hline & {$[\mathrm{R}($ int $)=0.0137]$} & {$[\mathrm{R}($ int $)=0.0162]$} & {$[\mathrm{R}($ int $)=0.0162]$} & {$[\mathrm{R}(\mathrm{int})=0.0569]$} \\
\hline Max. and Min. Transmission & 0.9151 and 0.8699 & 0.9678 and 0.9076 & 0.9451 and 0.9229 & 0.9662 and 0.9185 \\
\hline Data/ Restraints/ Parameters & $12540 / 1 / 523$ & $18618 / 155 / 1056$ & $16320 / 120 / 1064$ & $19956 / 120 / 1333$ \\
\hline Goodness of Fit on $F^{2}$ & 1.028 & 1.031 & 1.037 & 1.053 \\
\hline Final R Indices & $\mathrm{R}_{1}=0.0211$ & $\mathrm{R}_{1}=0.0726$ & $\mathrm{R}_{1}=0.0517$ & $\mathrm{R}_{1}=0.0897$ \\
\hline$[\mathrm{I}>2 \sigma(\mathrm{I})]$ & $\mathrm{wR}_{2}=0.0576$ & $\mathrm{wR}_{2}=0.1796$ & $\mathrm{wR}_{2}=0.1288$ & $\mathrm{wR}_{2}=0.223$ \\
\hline R Indices (All Data)* & $\mathrm{R}_{1}=0.0215$ & $\mathrm{R}_{1}=0.0905$ & $\mathrm{R}_{1}=0.0637$ & $\mathrm{R}_{1}=0.1364$ \\
\hline & $\mathrm{wR}_{2}=0.0577$ & $\mathrm{wR}_{2}=0.1924$ & $\mathrm{wR}_{2}=0.1383$ & $\mathrm{wR}_{2}=0.2562$ \\
\hline Largest Diff. Peak and Hole $\left(\mathrm{e} \AA^{-3}\right)$ & 0.366 and -0.298 & 1.577 and -1.024 & 1.589 and -1.031 & 1.532 and -1.793 \\
\hline
\end{tabular}

$* \mathrm{R}_{1}=\Sigma|| F_{o}|-| F_{o}|| / \Sigma\left|F_{o}\right| ; \mathrm{wR}_{2}=\left[\Sigma\left[w\left(F_{o}{ }^{2}-F_{c}{ }^{2}\right)^{2}\right] / \Sigma\left[w\left(F_{o}{ }^{2}\right)_{2}\right]\right]^{1 / 2} ; \mathrm{GOF}=\left[\Sigma\left[w\left(F_{o}{ }^{2}-F_{c}{ }^{2}\right)_{2}\right] /(n-p)\right]^{1 / 2}$, where $n$ is the number of reflections and $p$ is the total number of parameters refined. 


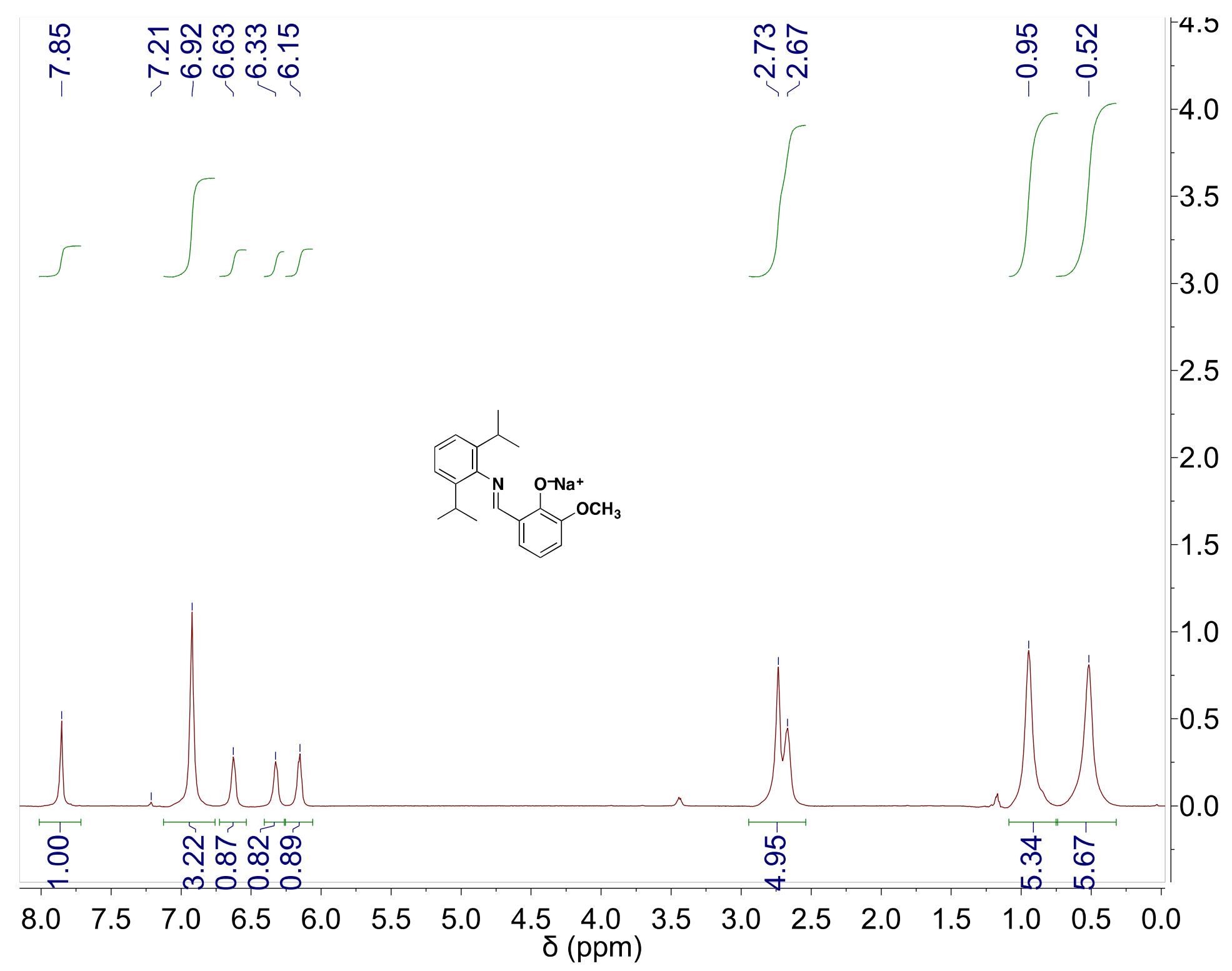

Figure S3. ${ }^{1} \mathrm{H}$ NMR spectrum $\left(\mathrm{CDCl}_{3}, 600 \mathrm{MHz}\right)$ of NaLO. 


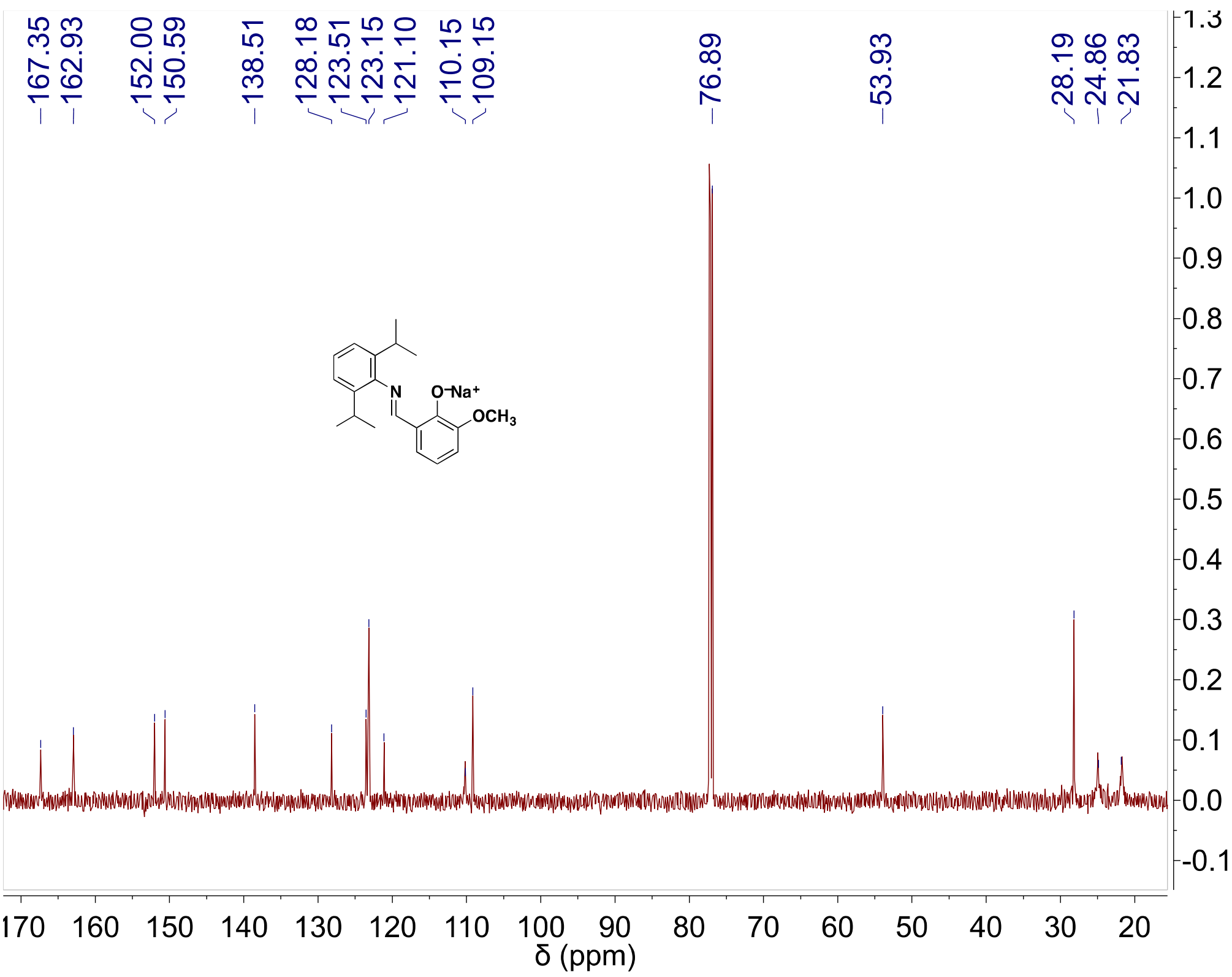

Figure S4. ${ }^{13} \mathrm{C}$ NMR spectrum $\left(\mathrm{CDCl}_{3}, 150 \mathrm{MHz}\right)$ of NaLO. 


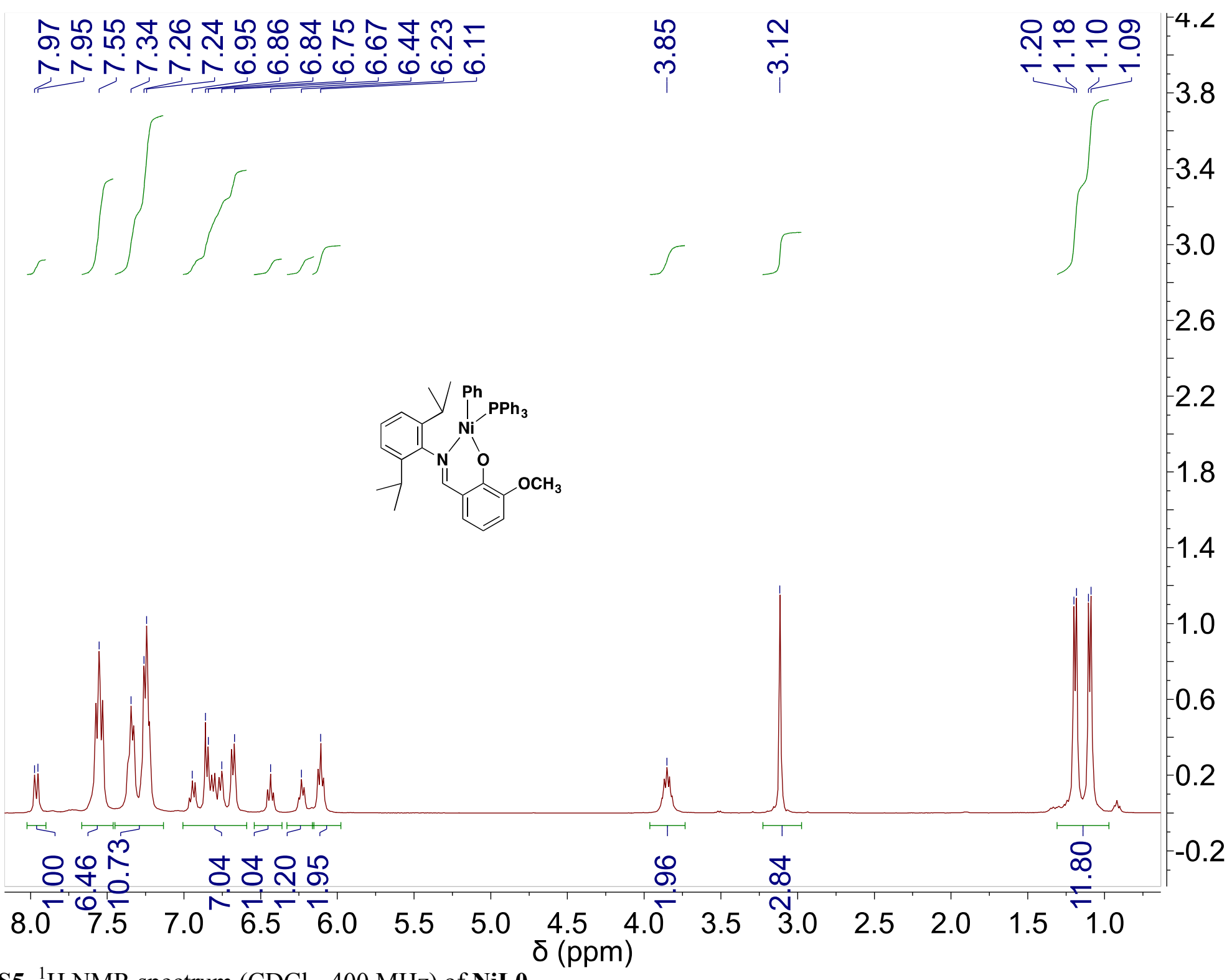

Figure S5. ${ }^{1} \mathrm{H}$ NMR spectrum $\left(\mathrm{CDCl}_{3}, 400 \mathrm{MHz}\right)$ of NiLo. 


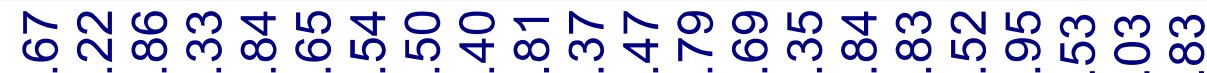
iि ڤீ

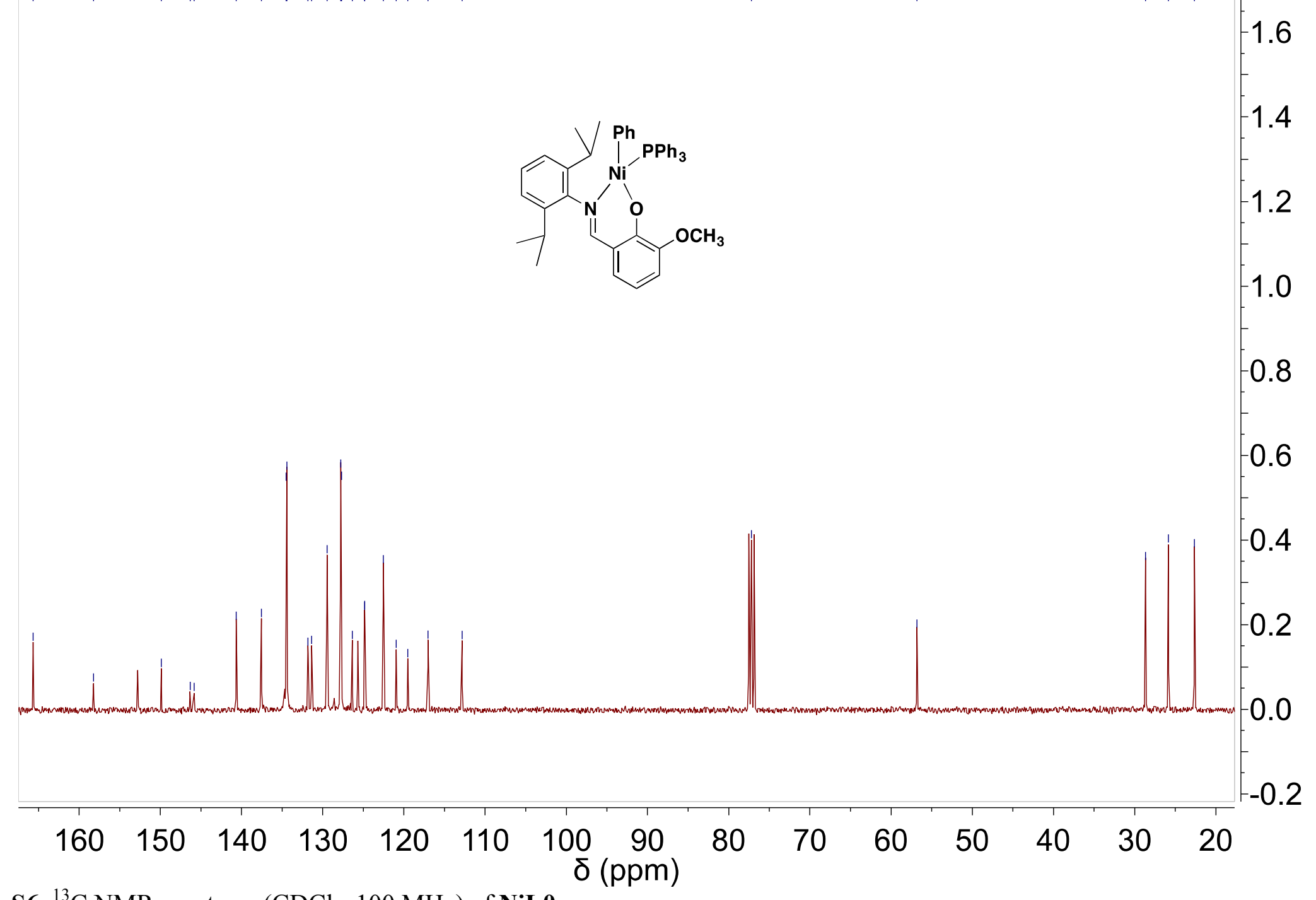

Figure S6. ${ }^{13} \mathrm{C}$ NMR spectrum $\left(\mathrm{CDCl}_{3}, 100 \mathrm{MHz}\right)$ of NiLo. 


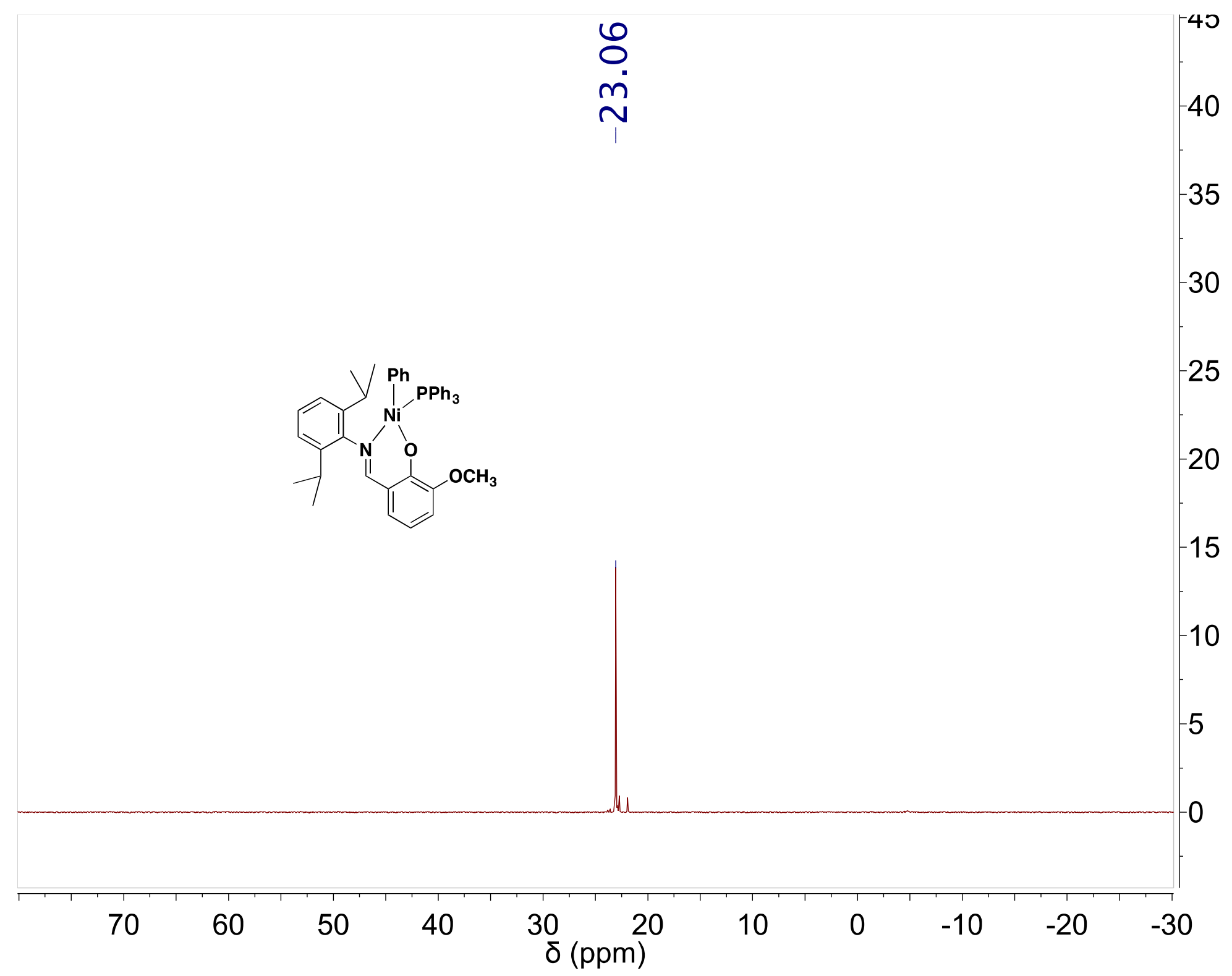

Figure S7. ${ }^{31} \mathrm{P}$ NMR spectrum $\left(\mathrm{CDCl}_{3}, 162 \mathrm{MHz}\right)$ of NiLo. 


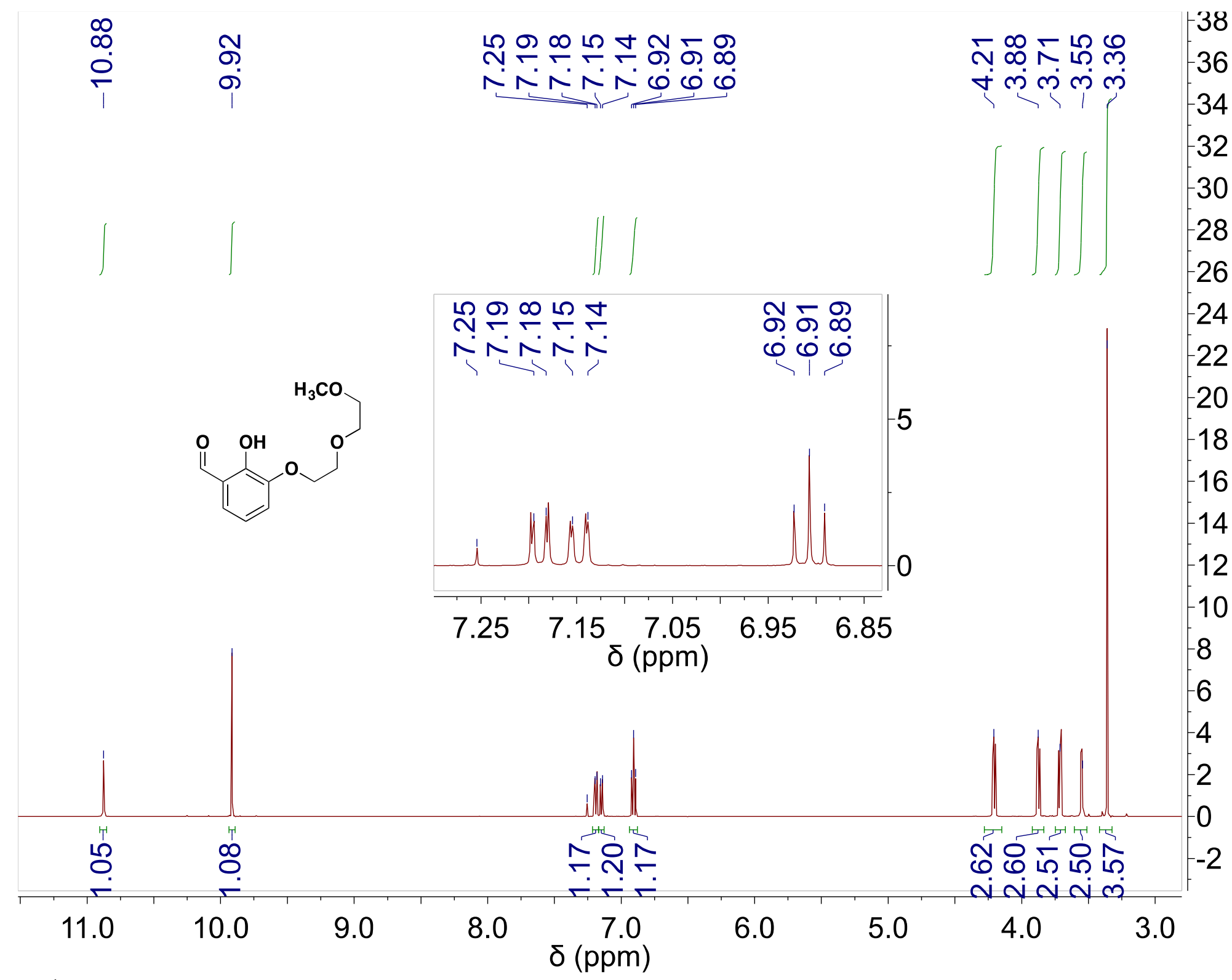

Figure S8. ${ }^{1} \mathrm{H} \mathrm{NMR}$ spectrum $\left(\mathrm{CDCl}_{3}, 400 \mathrm{MHz}\right)$ of aldehyde $\mathbf{1 C}$. 


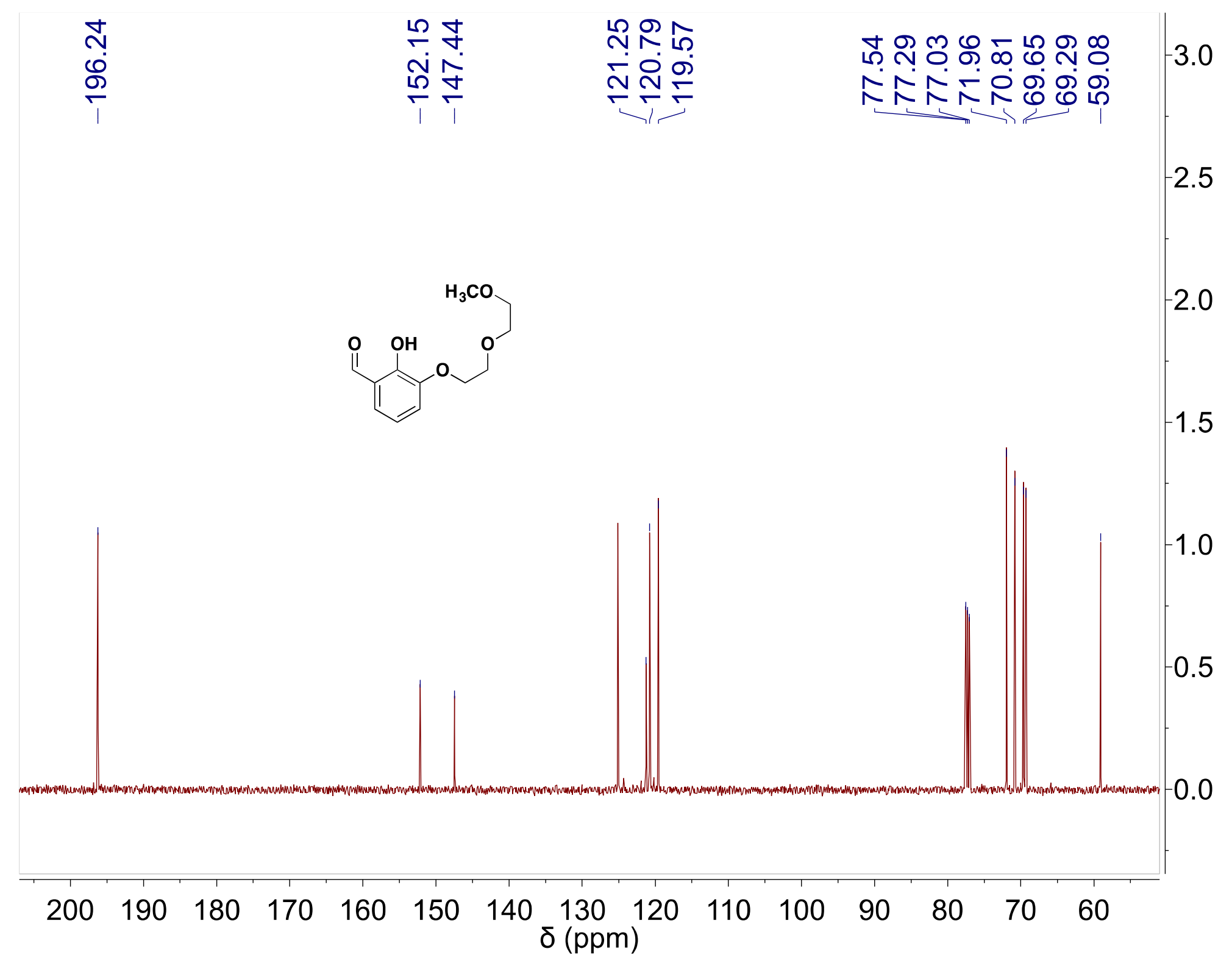

Figure S9. ${ }^{13} \mathrm{C}$ NMR spectrum $\left(\mathrm{CDCl}_{3}, 100 \mathrm{MHz}\right)$ of aldehyde $\mathbf{1 C}$. 


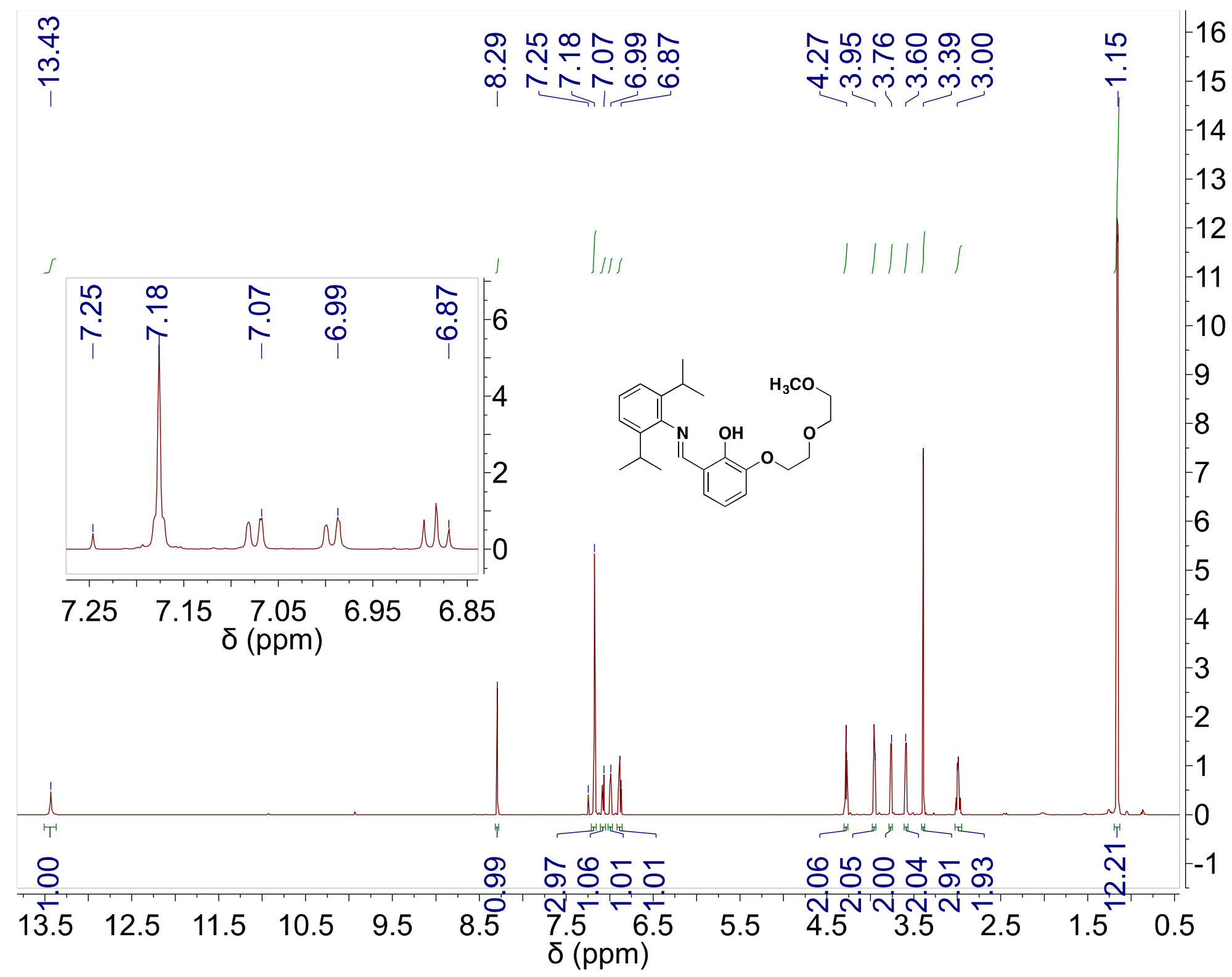

Figure S10. ${ }^{1} \mathrm{H}$ NMR spectrum $\left(\mathrm{CDCl}_{3}, 600 \mathrm{MHz}\right)$ of $\mathbf{H L 2}$. 


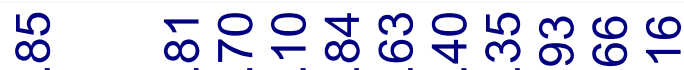

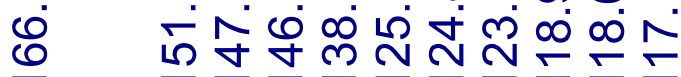

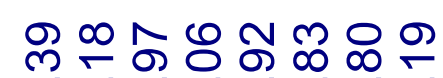

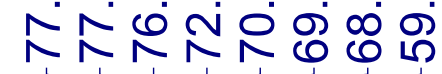

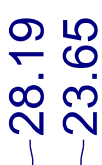

$\left.\stackrel{\nabla}{\check{r}}\right|_{-4.5} ^{-5.0}$

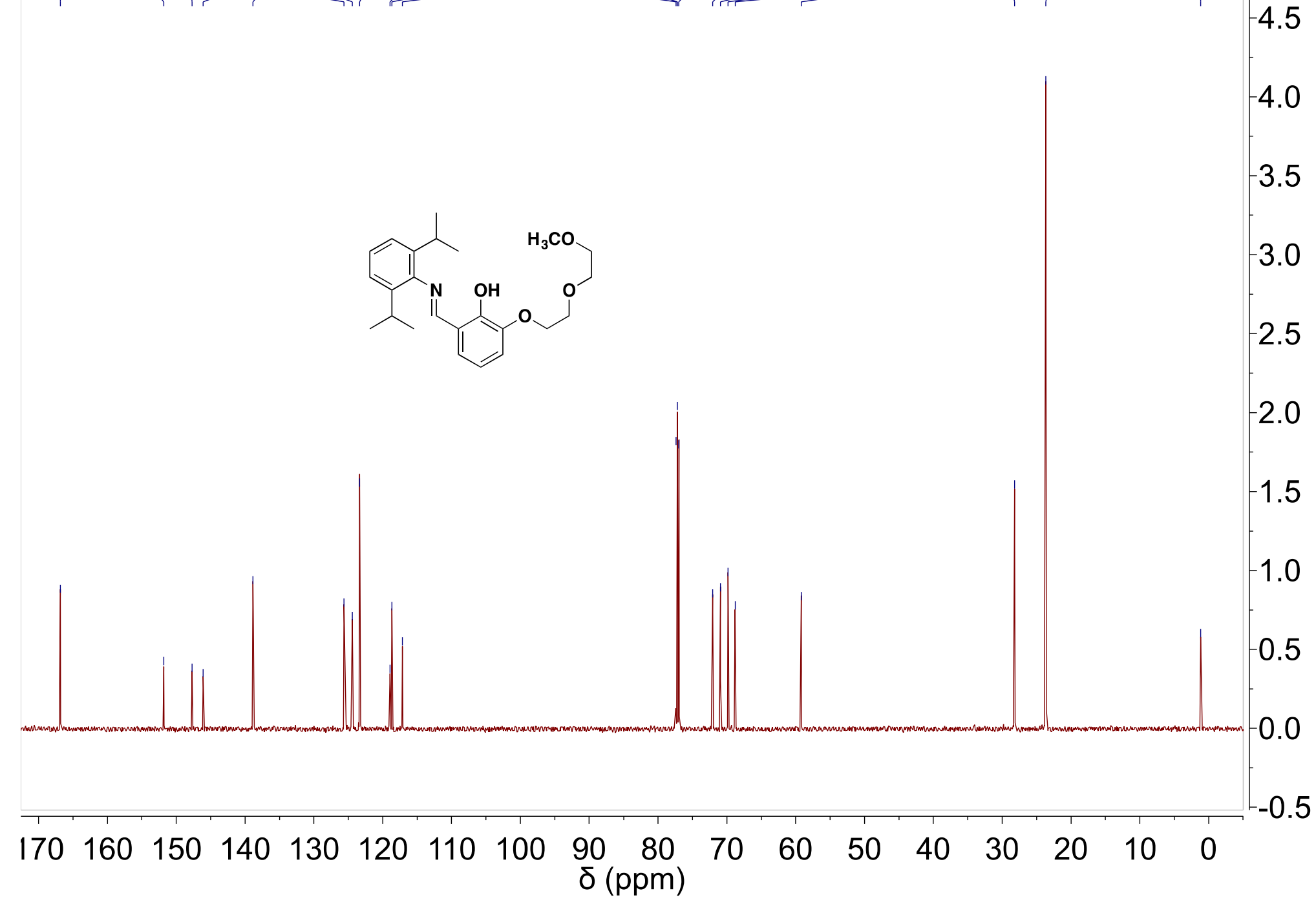

Figure S11. ${ }^{13} \mathrm{C}$ NMR spectrum $\left(\mathrm{CDCl}_{3}, 150 \mathrm{MHz}\right)$ of $\mathbf{H L 2}$. 


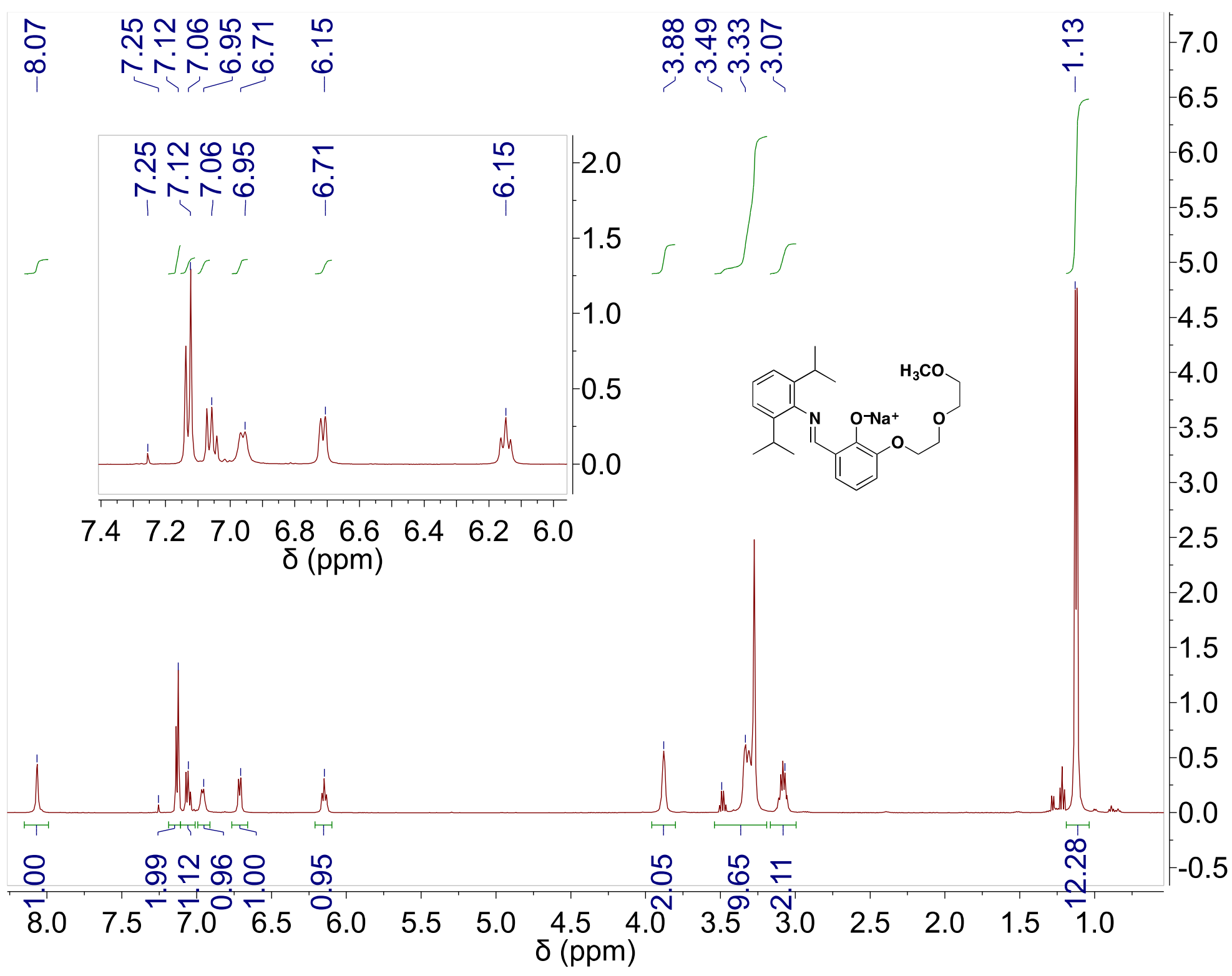

Figure S12. ${ }^{1} \mathrm{H}$ NMR $\left(\mathrm{CDCl}_{3}, 400 \mathrm{MHZ}\right)$ of NaL2. 


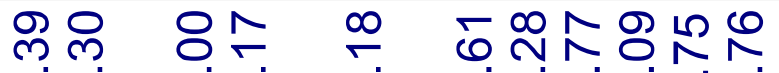

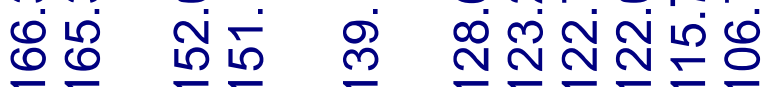

雨

Ñ்

온요운

Aี

0.45

0.40

0.35

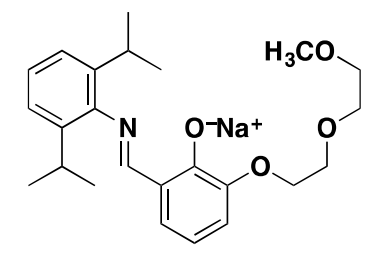

$-0.30$

0.25

0.20

0.15

0.10

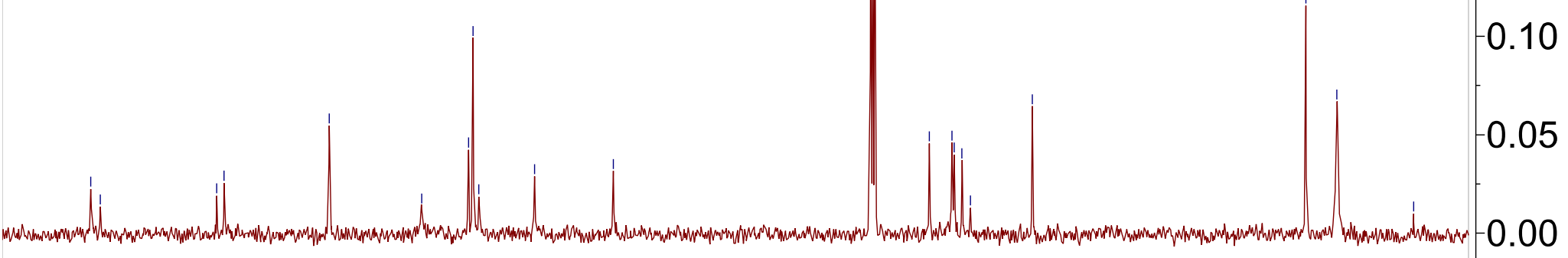

$-0.05$

$\begin{array}{llllllllllllllll}170 & 160 & 150 & 140 & 130 & 120 & 110 & \underset{\delta(\mathrm{ppm})}{100} \mathbf{9 0} & 80 & 70 & 60 & 50 & 40 & 30 & 20 & 10\end{array}$

Figure S13. ${ }^{13} \mathrm{C}$ NMR spectrum $\left(\mathrm{CDCl}_{3}, 100 \mathrm{MHz}\right)$ of NaL2. 
๑

ÑÑ

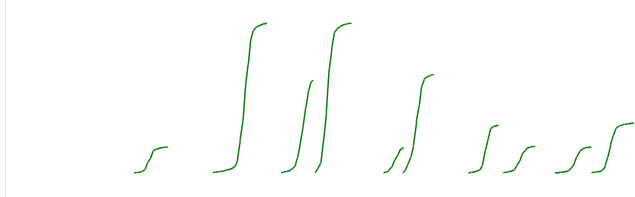

$\infty$ กิ กั

ल लंख

$\stackrel{m}{\check{2}}$

$-3.2$

3.0

2.8

2.6

2.4

2.2

2.0
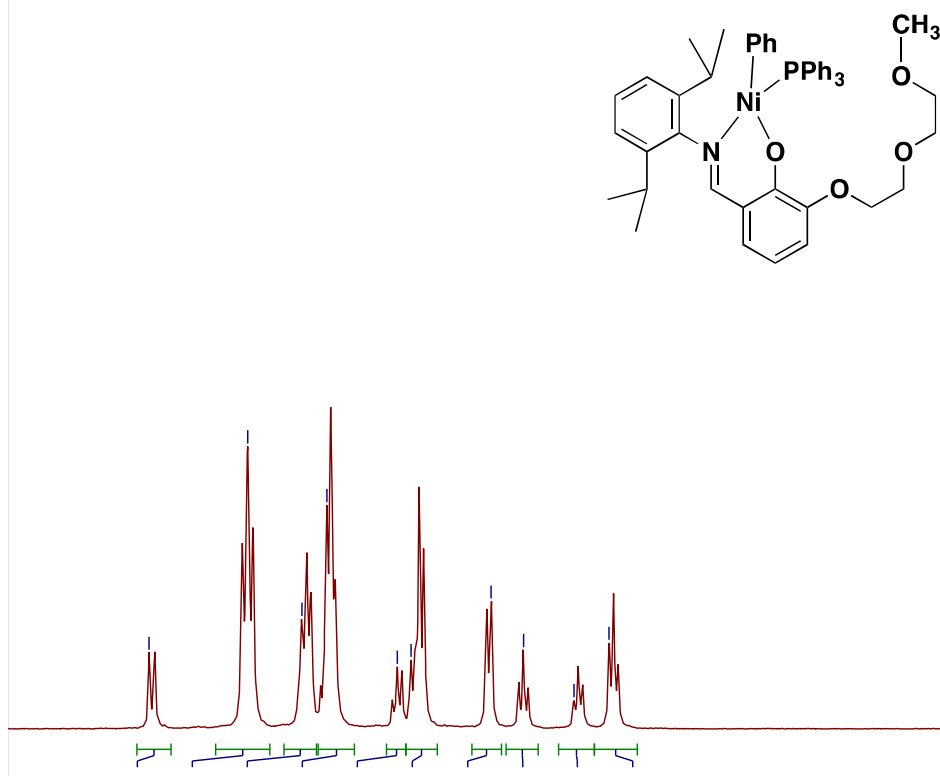

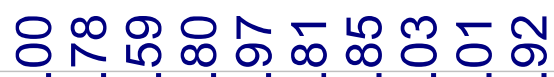

8.07 .57 .06 .56 .0

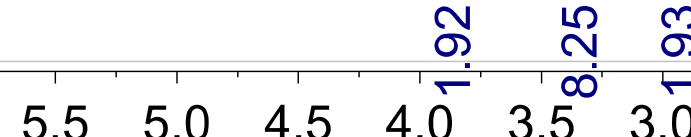

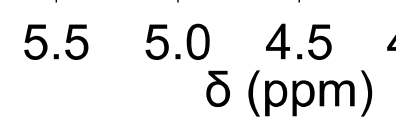

1.8

1.6

1.4

1.2

1.0

0.8

0.6

0.4

0.2

0.0

లి $\quad-0.2$

Figure S14. ${ }^{1} \mathrm{H}$ NMR spectrum $\left(\mathrm{CDCl}_{3}, 400 \mathrm{MHz}\right)$ of NiL2. 
$N 6+\sigma \infty m 00+\infty \sim \infty \sim 6)$

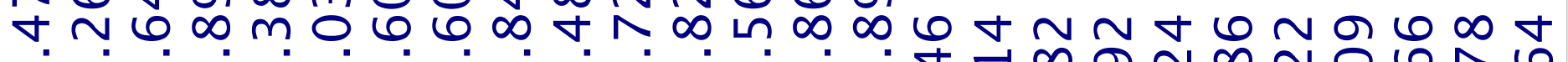
म

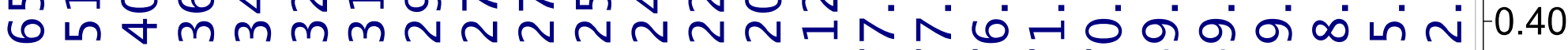
形年

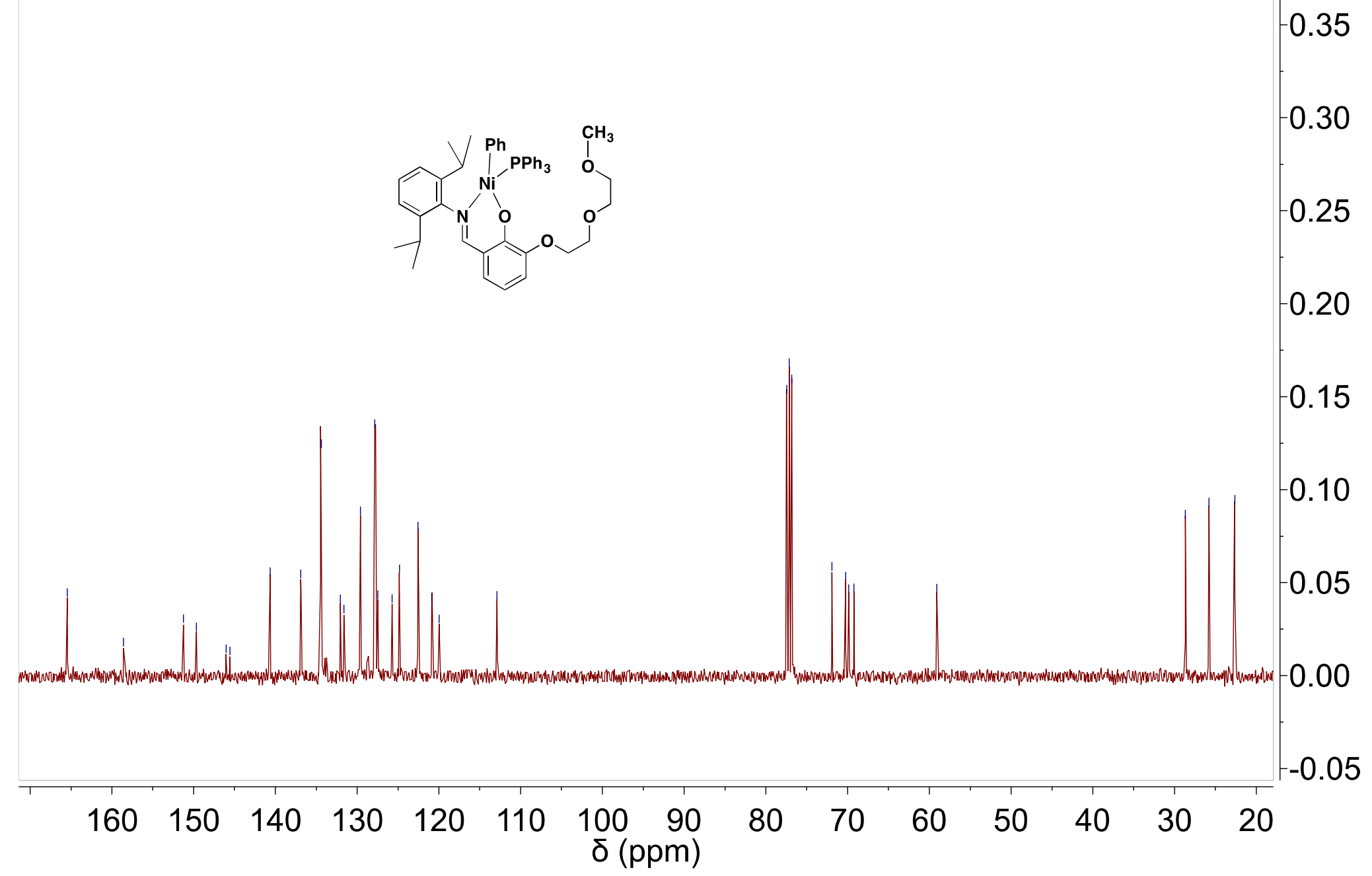

Figure S15. ${ }^{13} \mathrm{C}$ NMR spectrum $\left(\mathrm{CDCl}_{3}, 100 \mathrm{MHz}\right)$ of NiL2. 


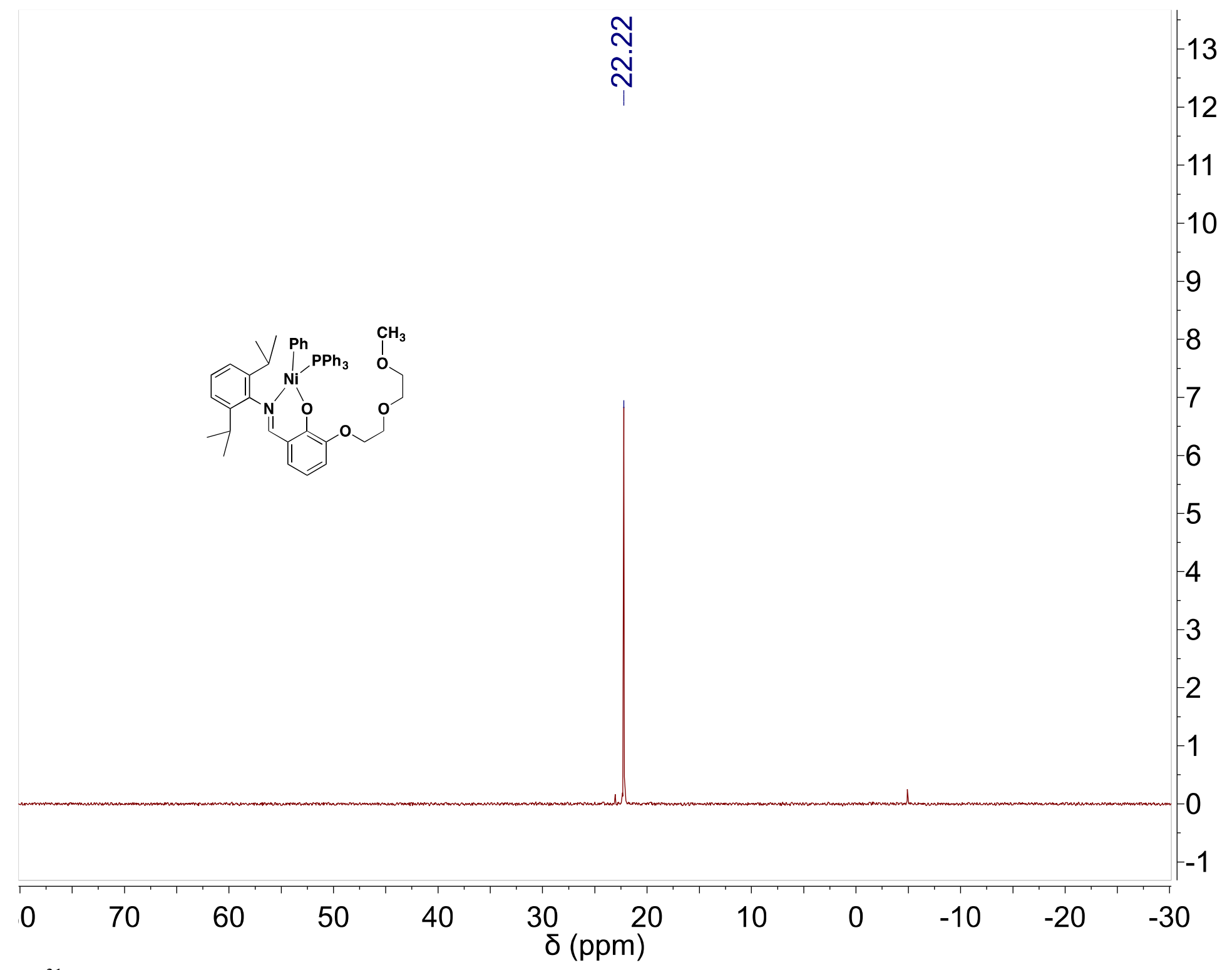

Figure S16. ${ }^{31} \mathrm{P}$ NMR spectrum $\left(\mathrm{CDCl}_{3}, 162 \mathrm{MHz}\right)$ of NiL2. 

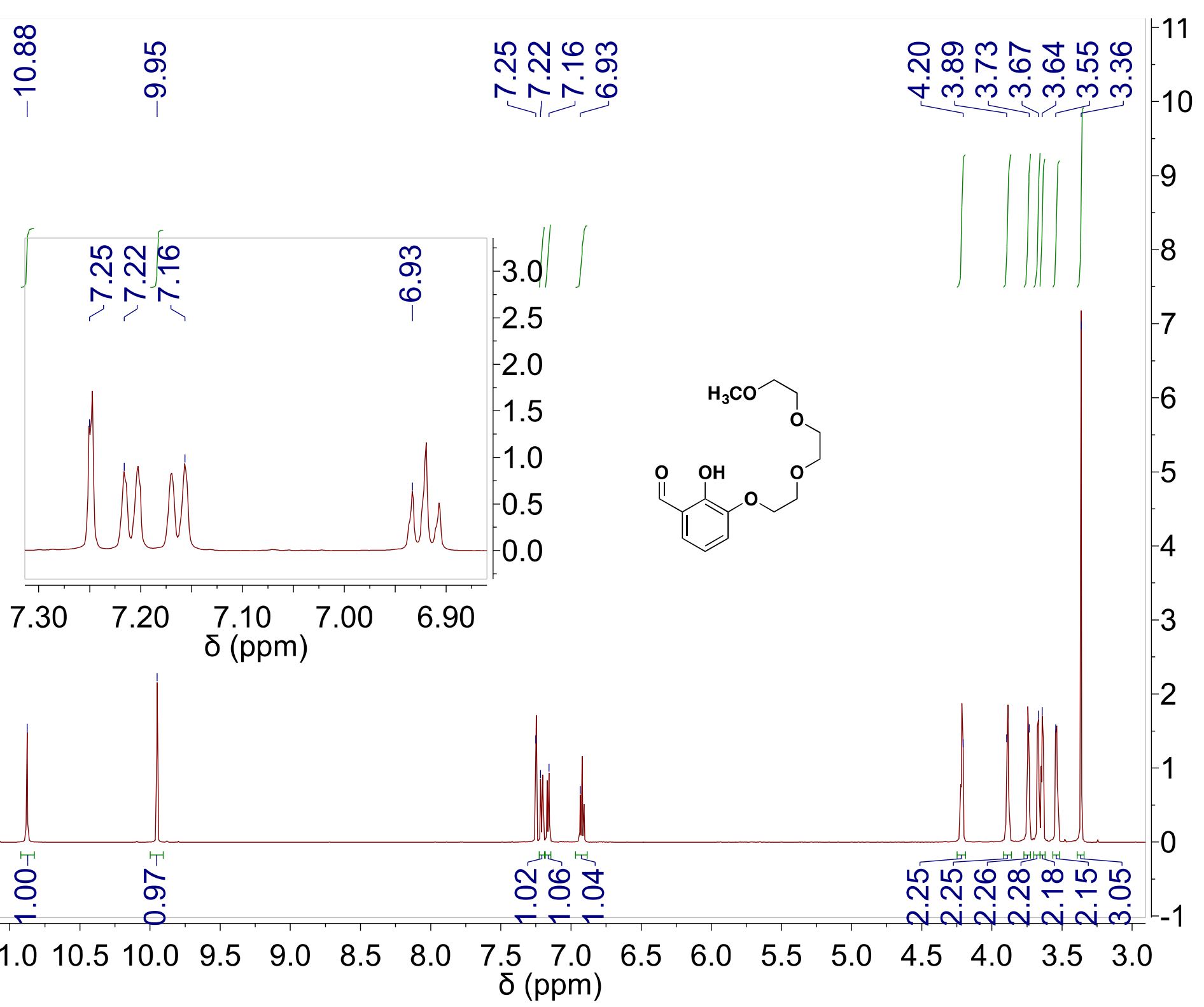

Figure S17. ${ }^{1} \mathrm{H} \mathrm{NMR}\left(\mathrm{CDCl}_{3}, 600 \mathrm{MHz}\right)$ of aldehyde $1 \mathrm{D}$. 


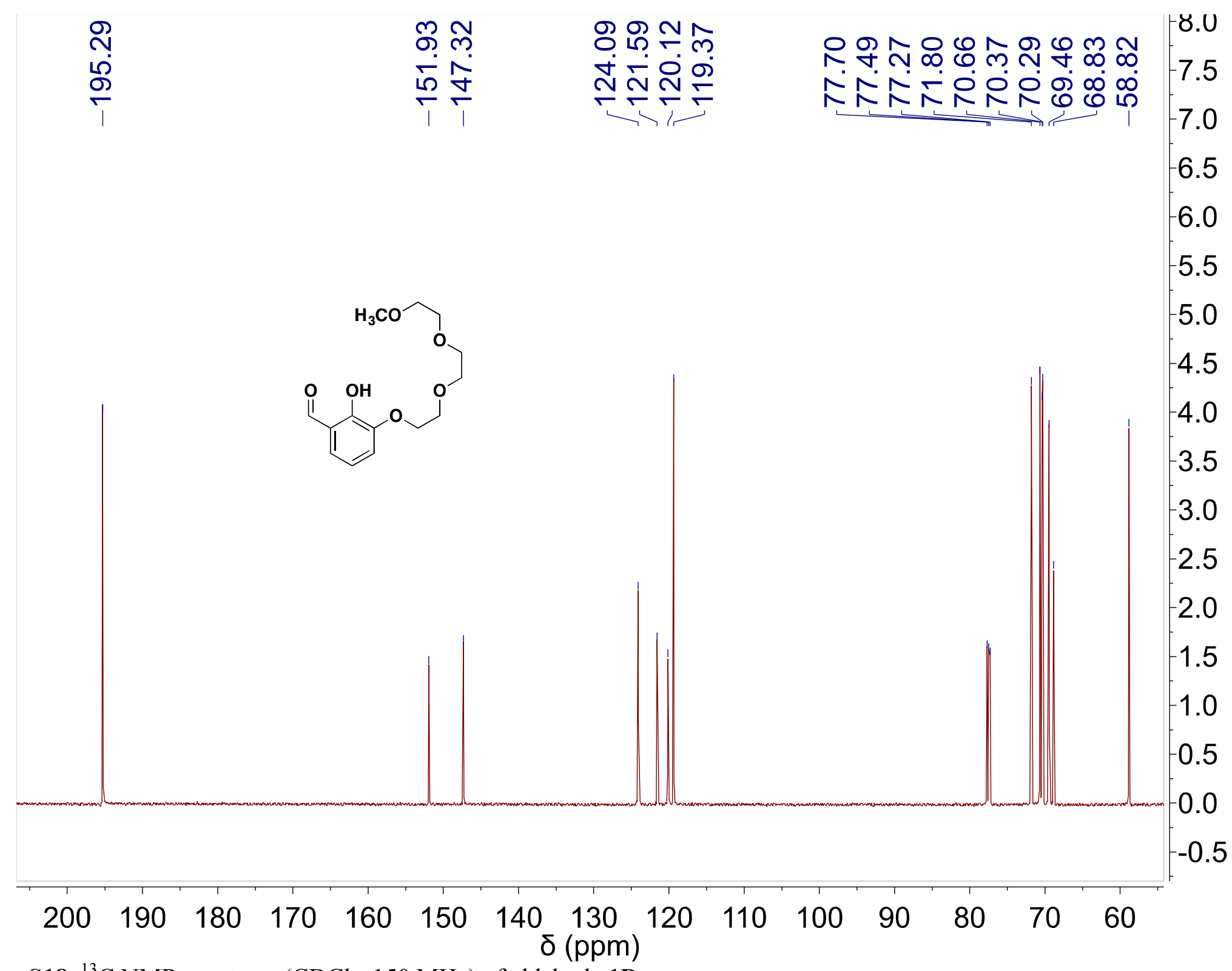

Figure S18. ${ }^{13} \mathrm{C}$ NMR spectrum $\left(\mathrm{CDCl}_{3}, 150 \mathrm{MHz}\right)$ of aldehyde $1 \mathrm{D}$. 


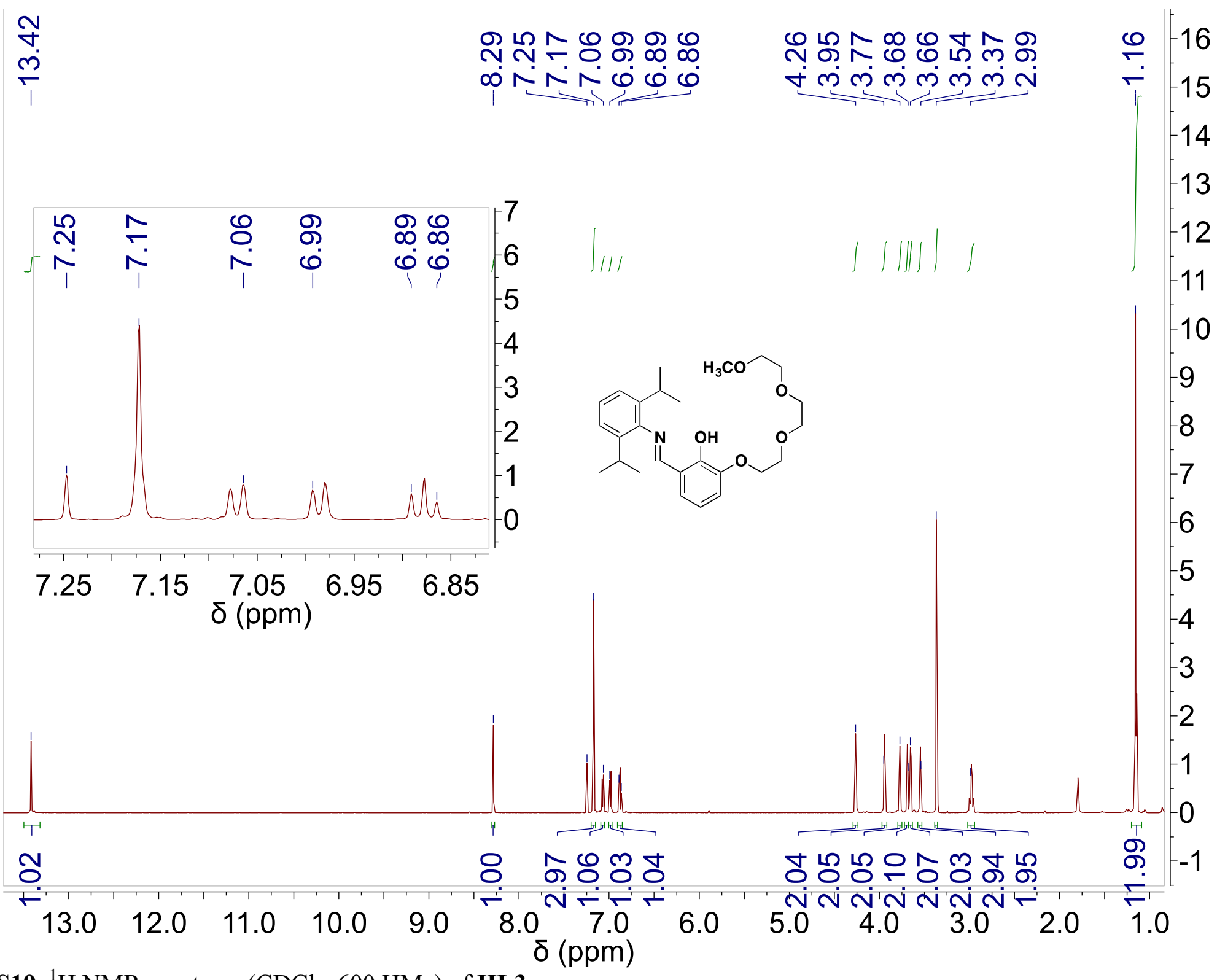

Figure S19. ${ }^{1} \mathrm{H}$ NMR spectrum $\left(\mathrm{CDCl}_{3}, 600 \mathrm{HMz}\right)$ of $\mathbf{H L 3}$. 


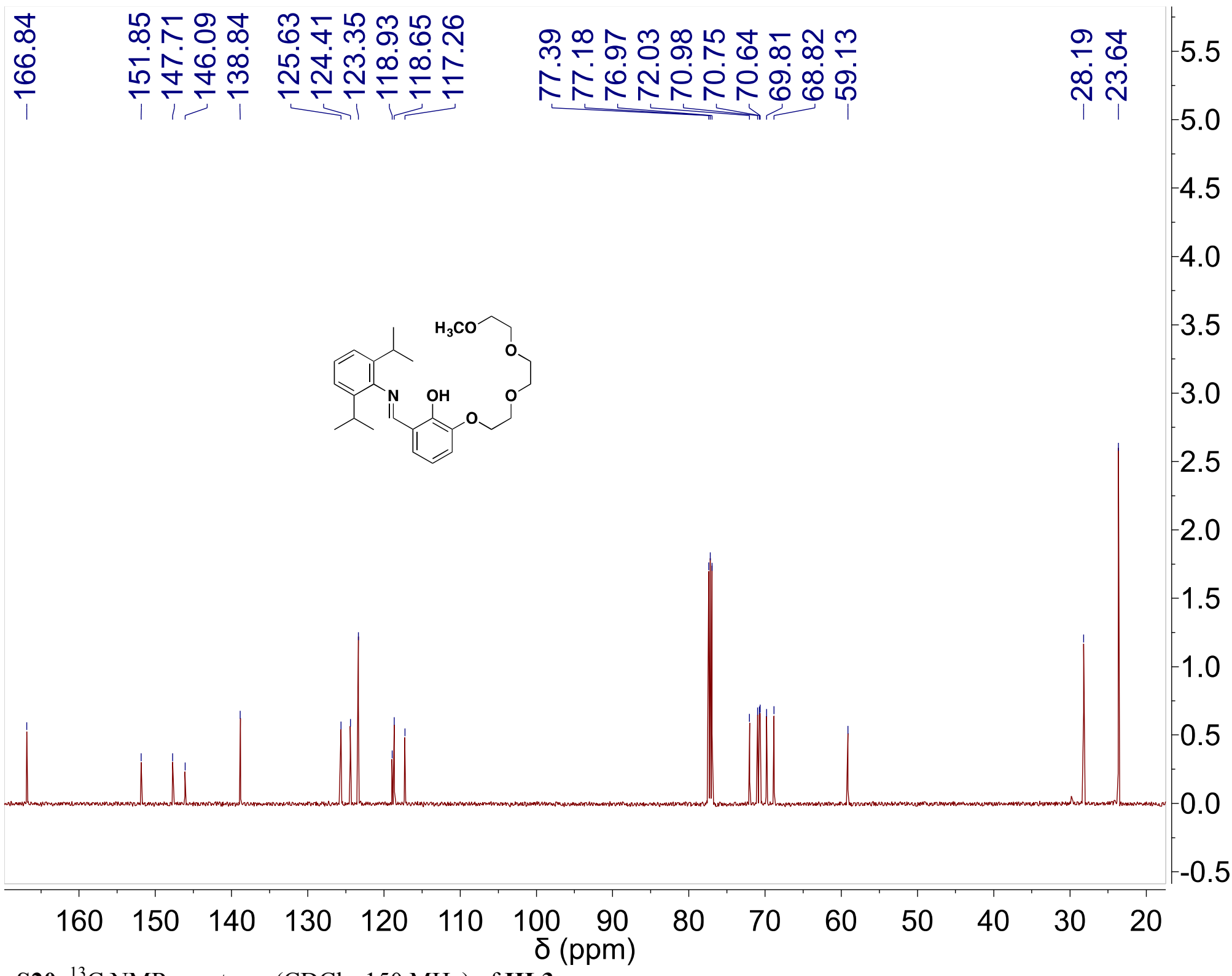

Figure S20. ${ }^{13} \mathrm{C}$ NMR spectrum $\left(\mathrm{CDCl}_{3}, 150 \mathrm{MHz}\right)$ of HL3. 


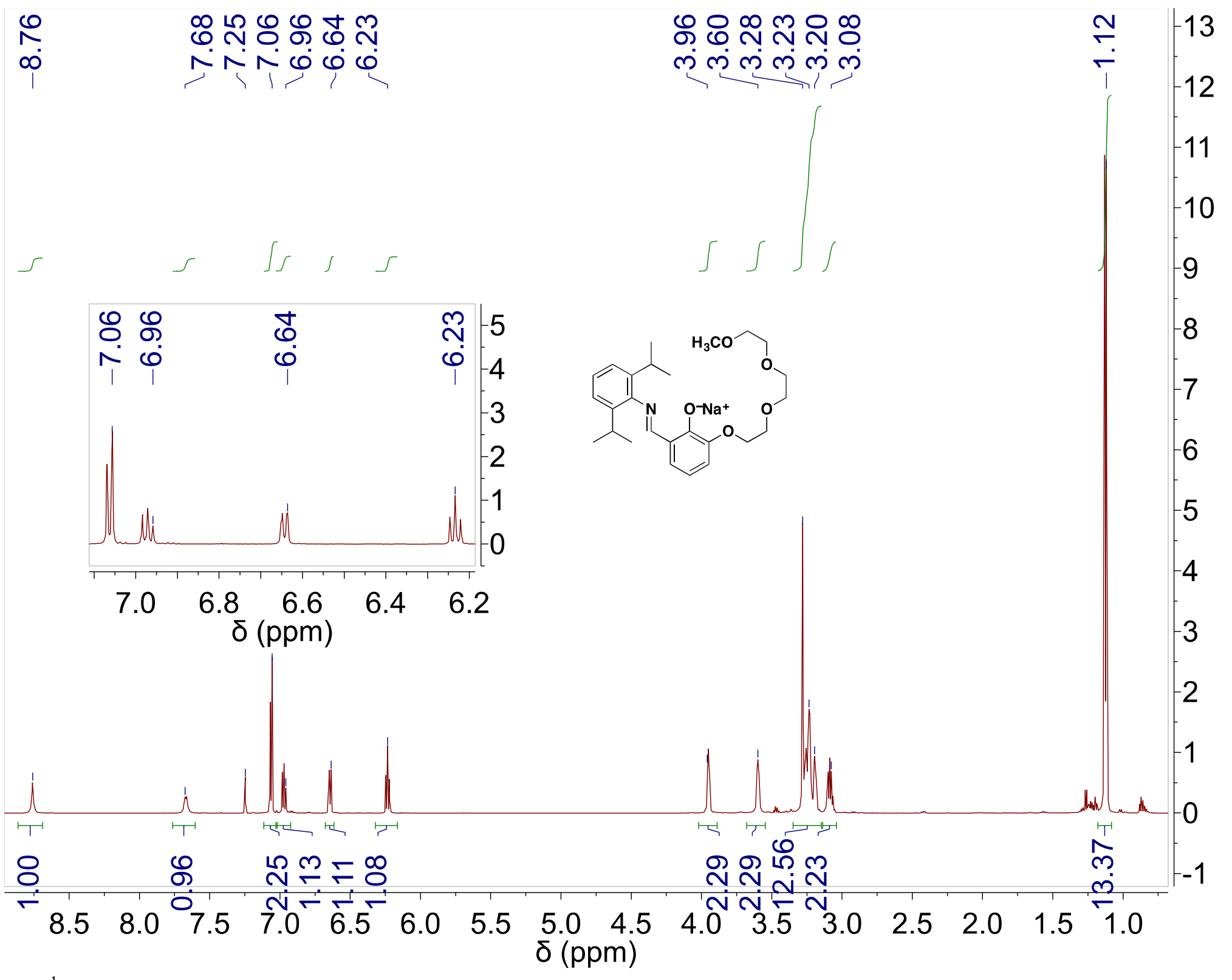

Figure S21. ${ }^{1} \mathrm{H}$ NMR spectrum $\left(\mathrm{CDCl}_{3}, 600 \mathrm{MHz}\right)$ of $\mathbf{N a L 3}$. 


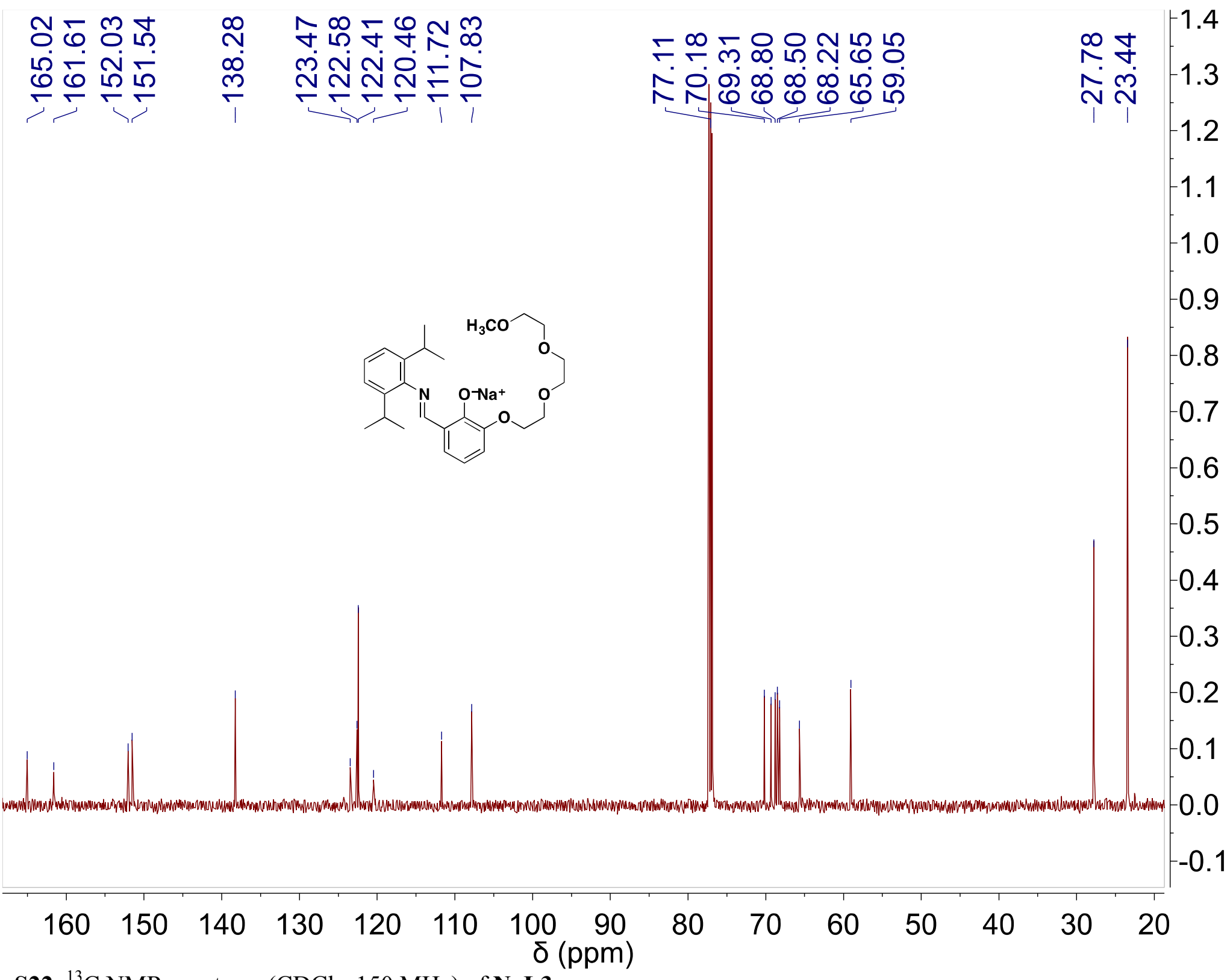

Figure S22. ${ }^{13} \mathrm{C}$ NMR spectrum $\left(\mathrm{CDCl}_{3}, 150 \mathrm{MHz}\right)$ of $\mathbf{N a L 3}$. 


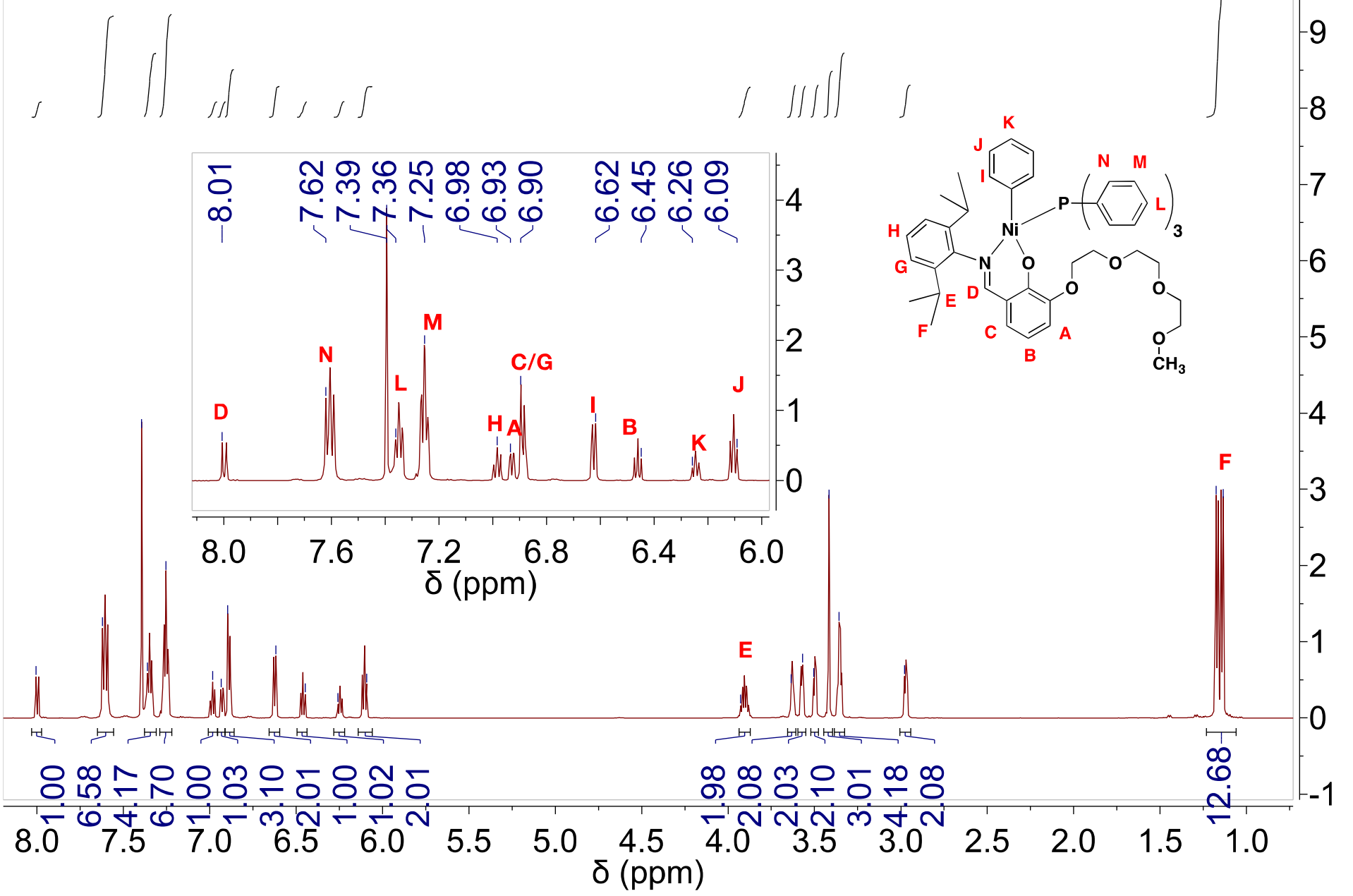

Figure S23. ${ }^{1} \mathrm{H}$ NMR spectrum $\left(\mathrm{CDCl}_{3}, 600 \mathrm{MHz}\right)$ of NiL3. Spectral assignments were aided by the COSY data (Figure S26). 


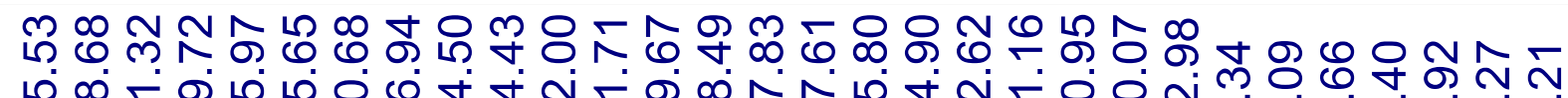

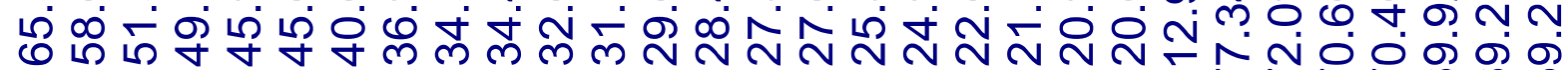

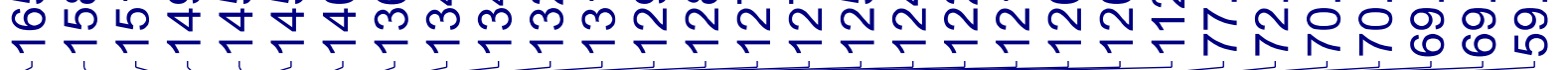

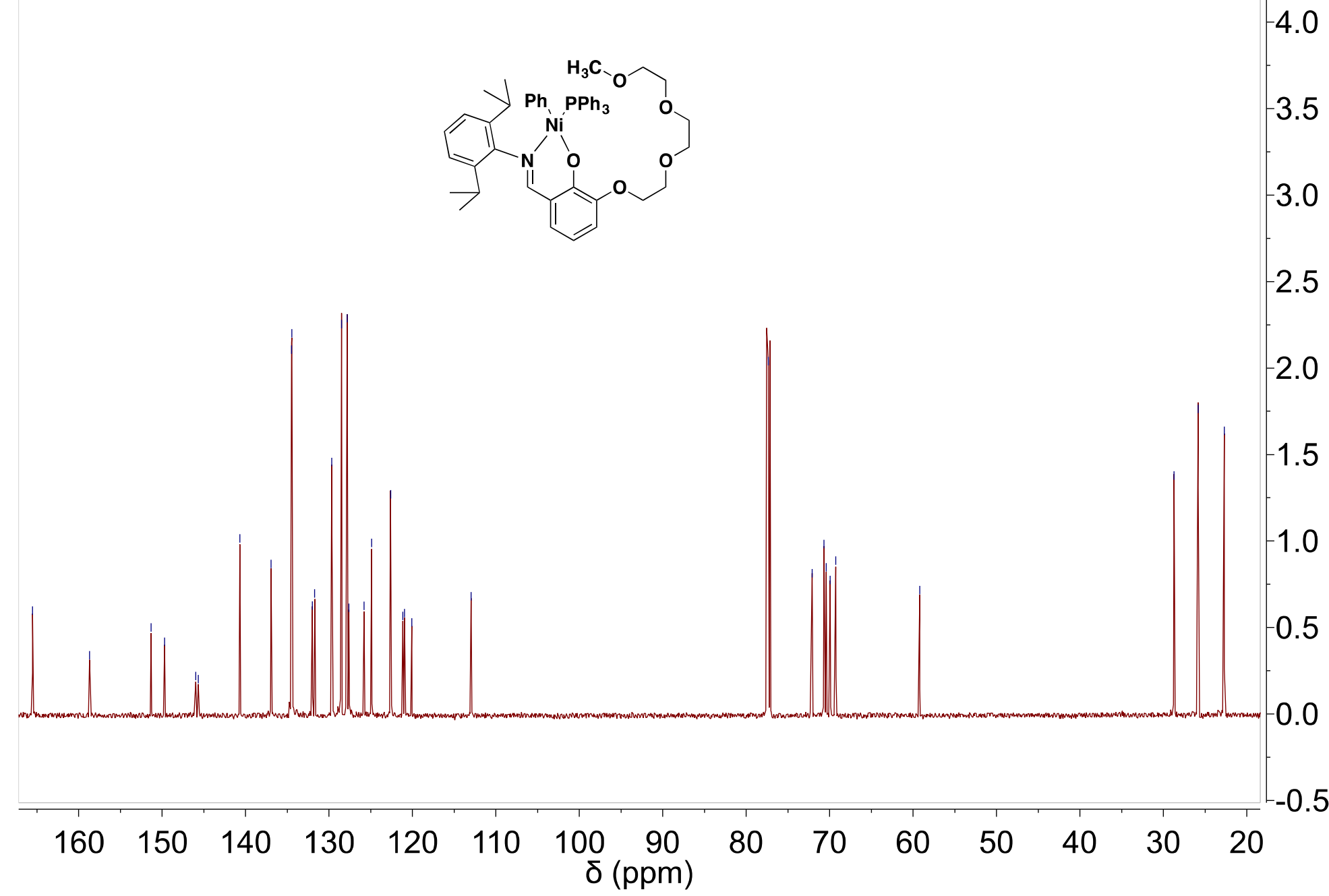

Figure S24. ${ }^{13} \mathrm{C}$ NMR spectrum $\left(\mathrm{CDCl}_{3}, 150 \mathrm{MHz}\right)$ of NiL3. 


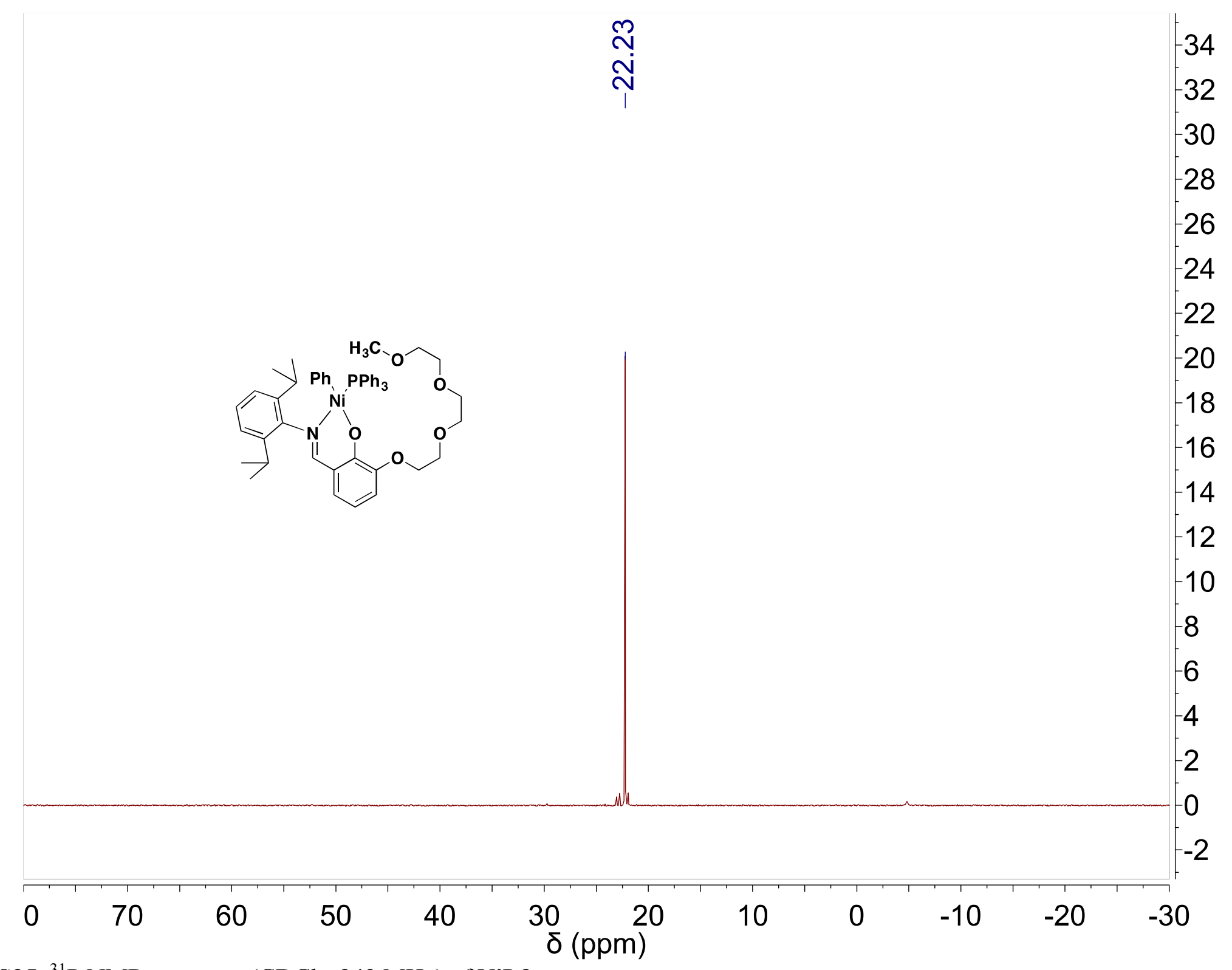

Figure S25. ${ }^{31} \mathrm{P}$ NMR spectrum $\left(\mathrm{CDCl}_{3}, 243 \mathrm{MHz}\right)$ of NiL3. 


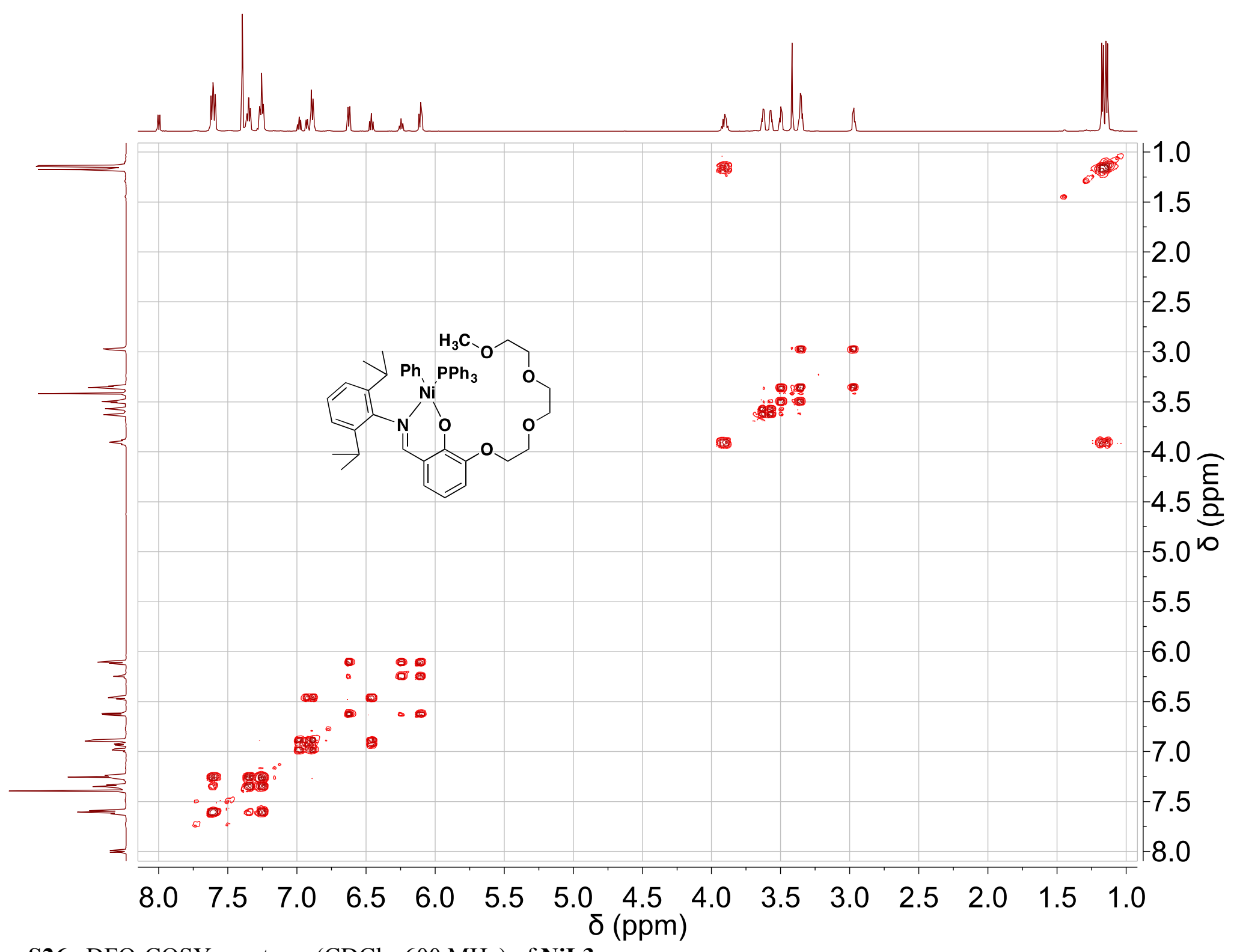

Figure S26. DFQ-COSY spectrum $\left(\mathrm{CDCl}_{3}, 600 \mathrm{MHz}\right)$ of NiL3. 


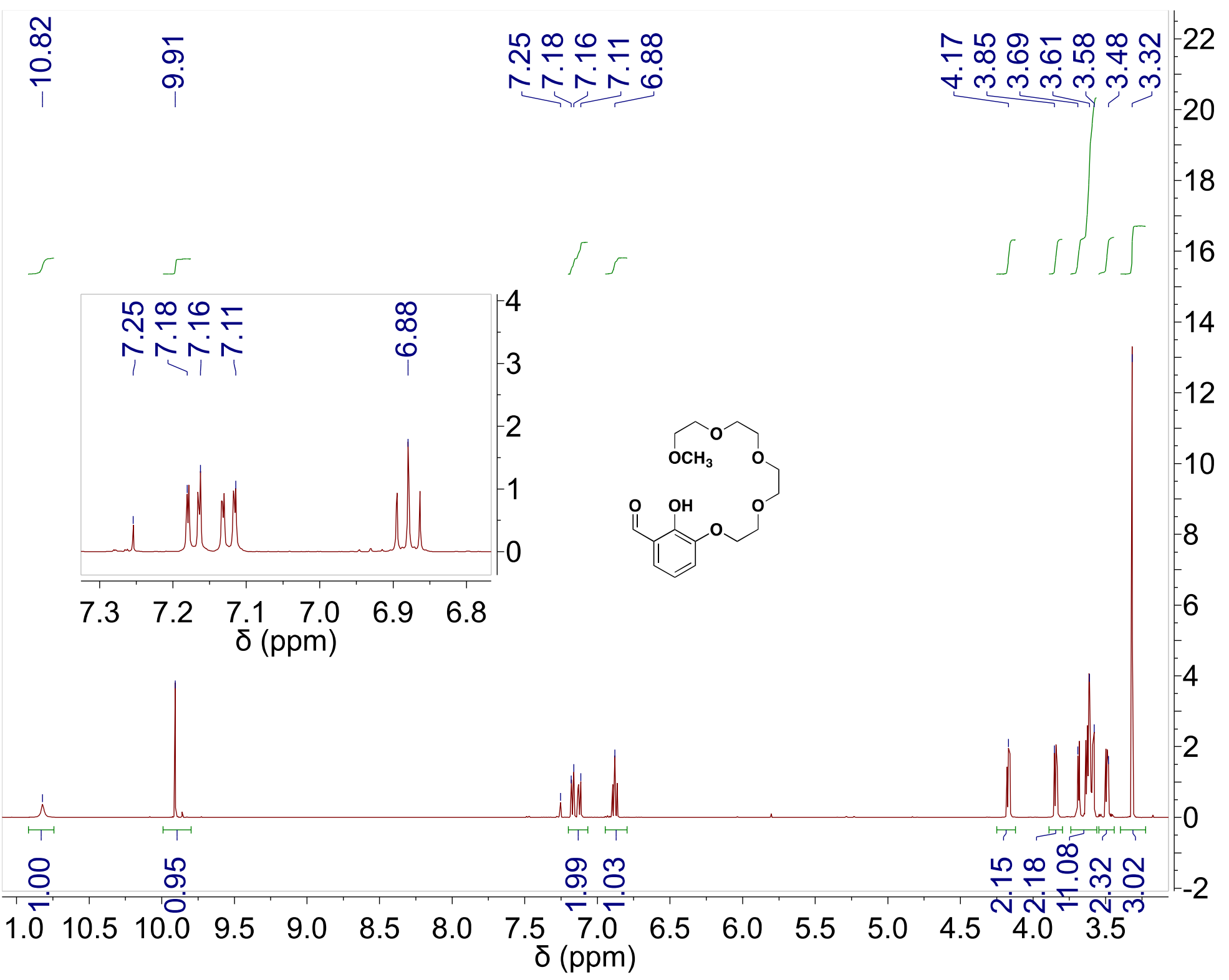

Figure S27. ${ }^{1} \mathrm{H}$ NMR spectrum $\left(\mathrm{CDCl}_{3}, 500 \mathrm{MHz}\right)$ of aldehyde $\mathbf{1 E}$. 


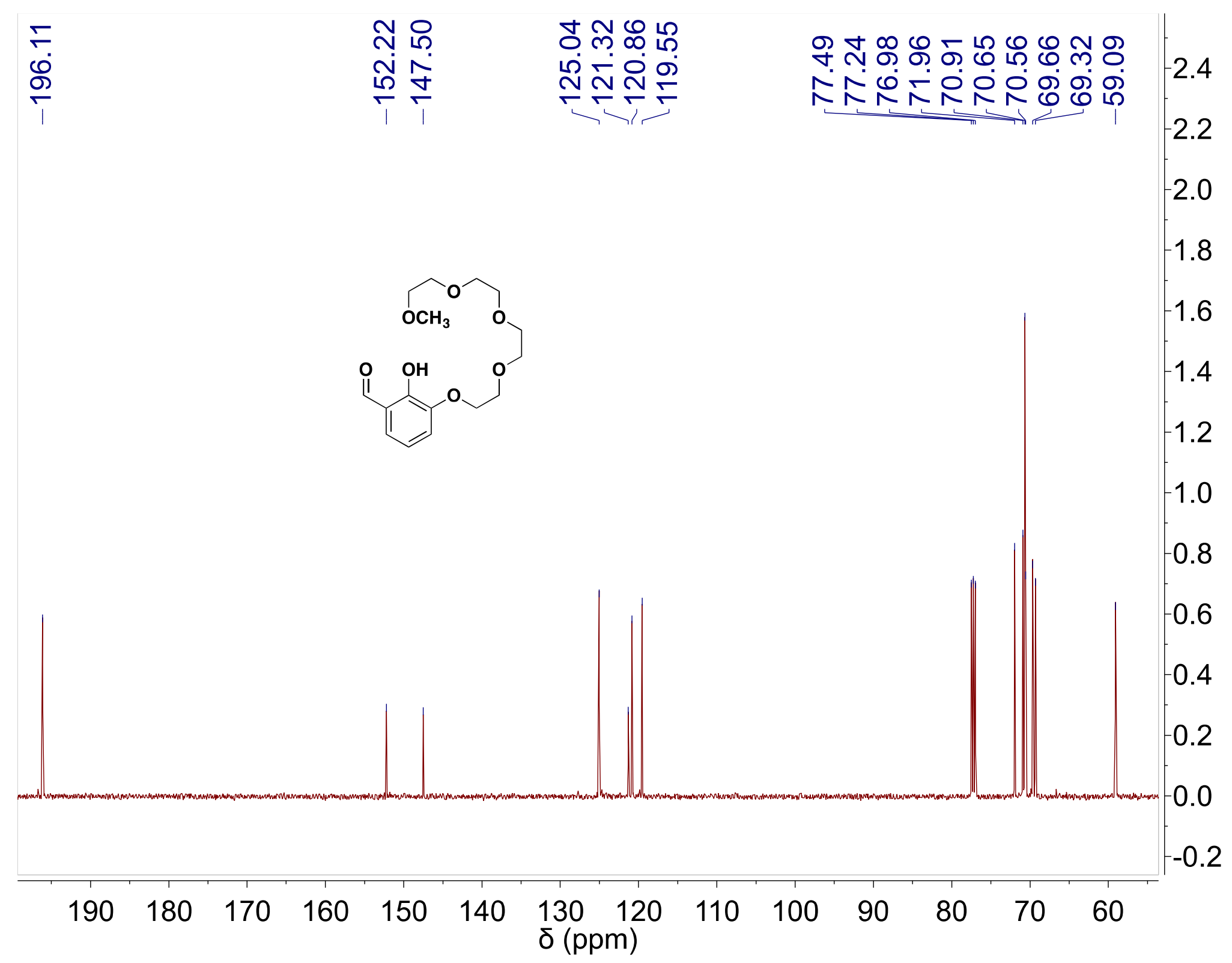

Figure S28. ${ }^{13} \mathrm{C}$ NMR spectrum $\left(\mathrm{CDCl}_{3}, 125 \mathrm{MHz}\right)$ of aldehyde $\mathbf{1 E}$. 


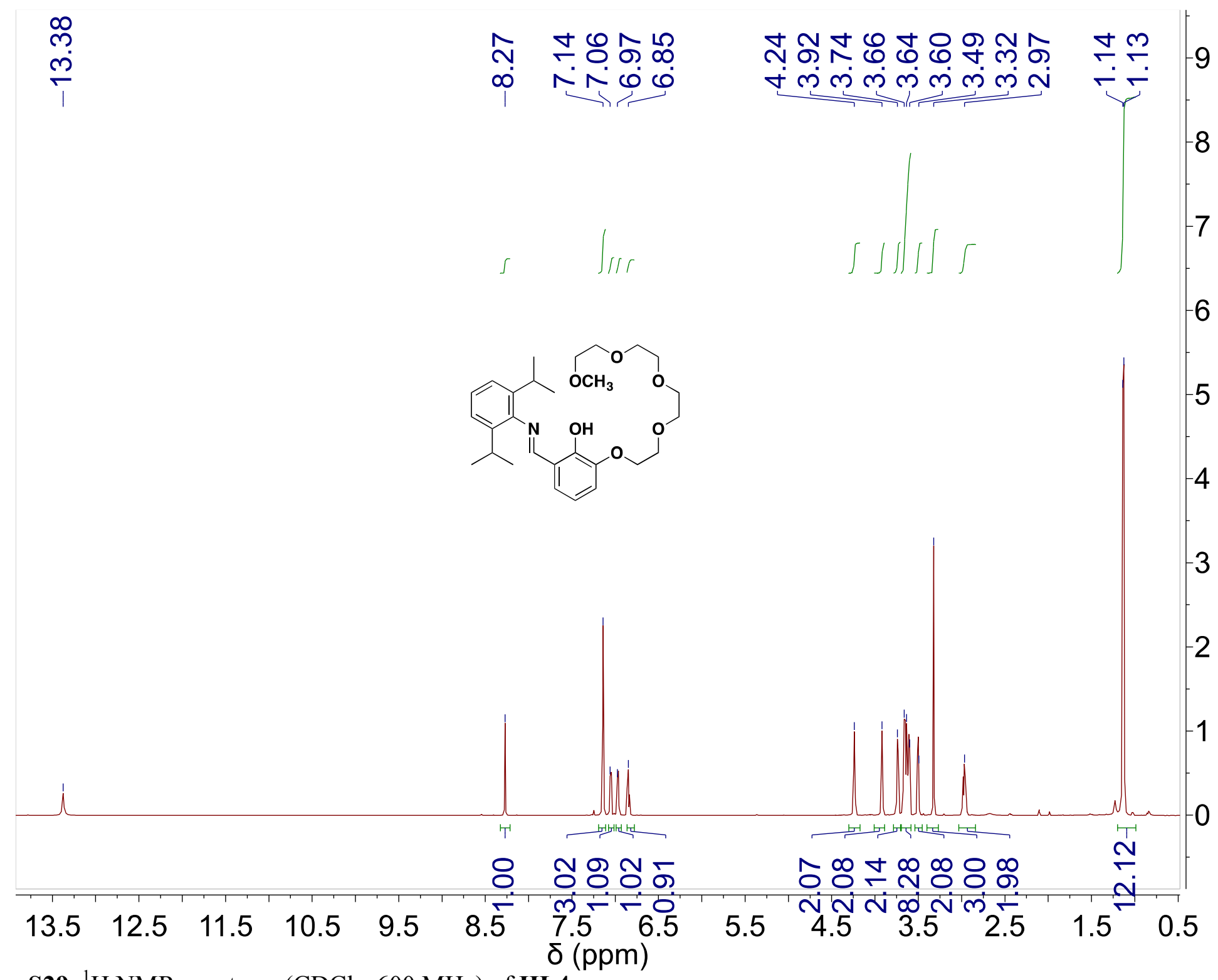

Figure S29. ${ }^{1} \mathrm{H}$ NMR spectrum $\left(\mathrm{CDCl}_{3}, 600 \mathrm{MHz}\right)$ of $\mathbf{H L 4}$. 


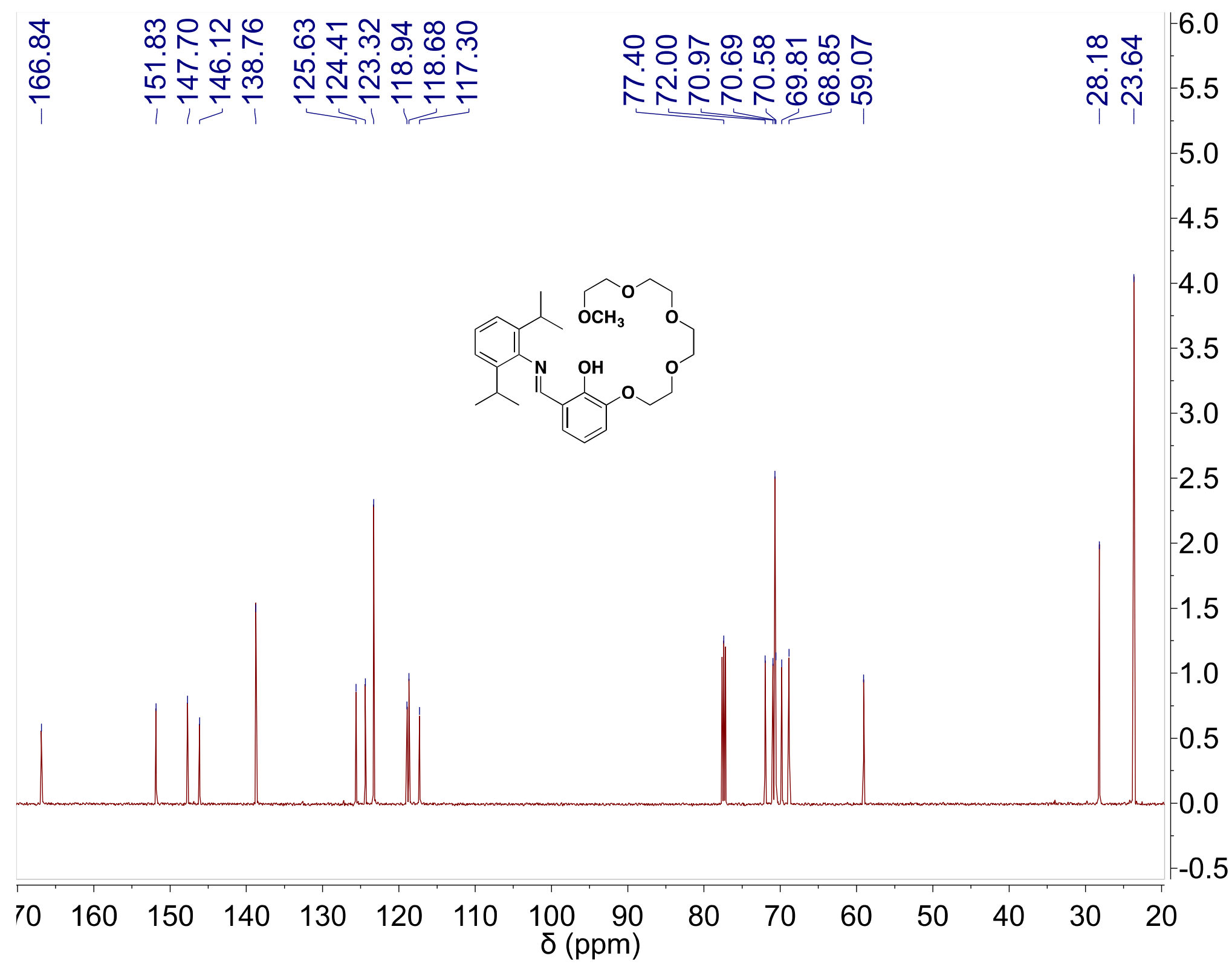

Figure S30. ${ }^{13} \mathrm{C}$ NMR spectrum $\left(\mathrm{CDCl}_{3}, 150 \mathrm{MHz}\right)$ of $\mathbf{H L 4}$. 


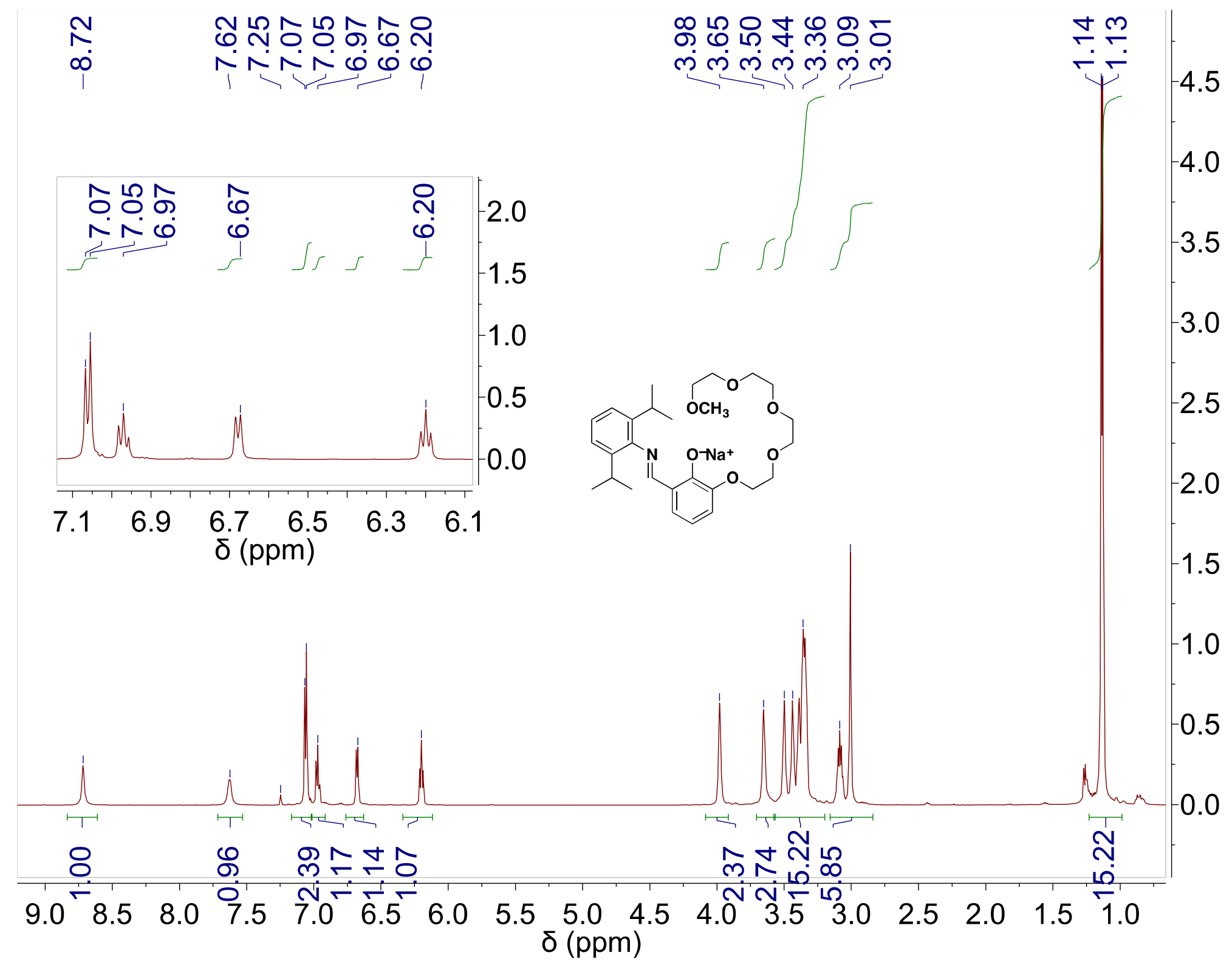

Figure S31. ${ }^{1} \mathrm{H}$ NMR spectrum $\left(\mathrm{CDCl}_{3}, 600 \mathrm{MHz}\right)$ of NaL4. 
웅ㅇㅇㅇㅛ 웅

色

นึ่ ชิ กิ

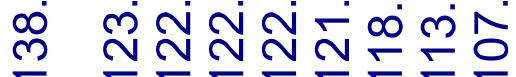

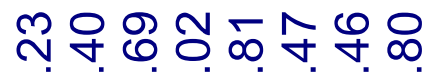

人下す

2.4

$\dot{r} \leftarrow$
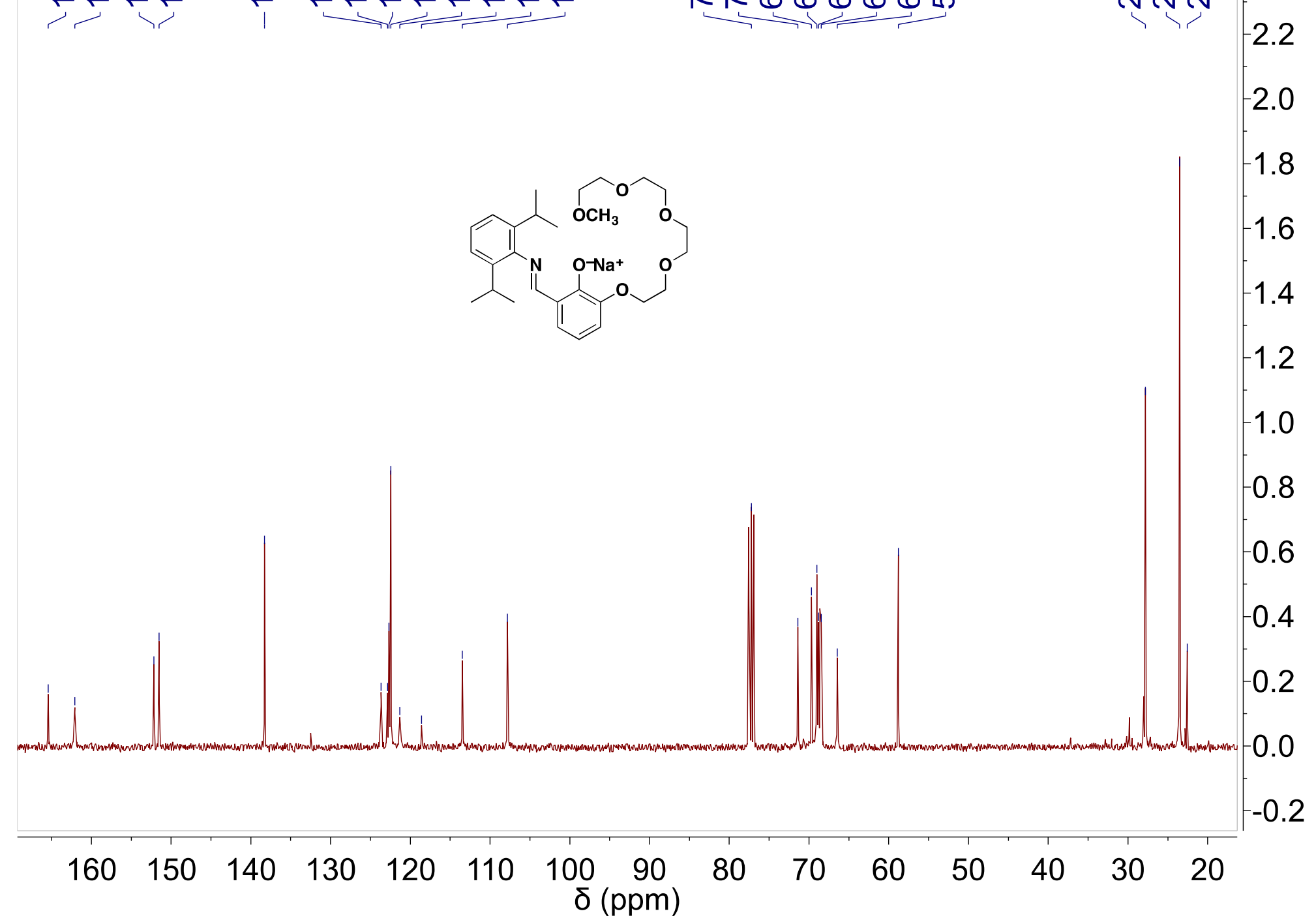

Figure S32. ${ }^{13} \mathrm{C}$ NMR spectrum $\left(\mathrm{CDCl}_{3}, 100 \mathrm{MHz}\right)$ of $\mathbf{N a L 4}$. 


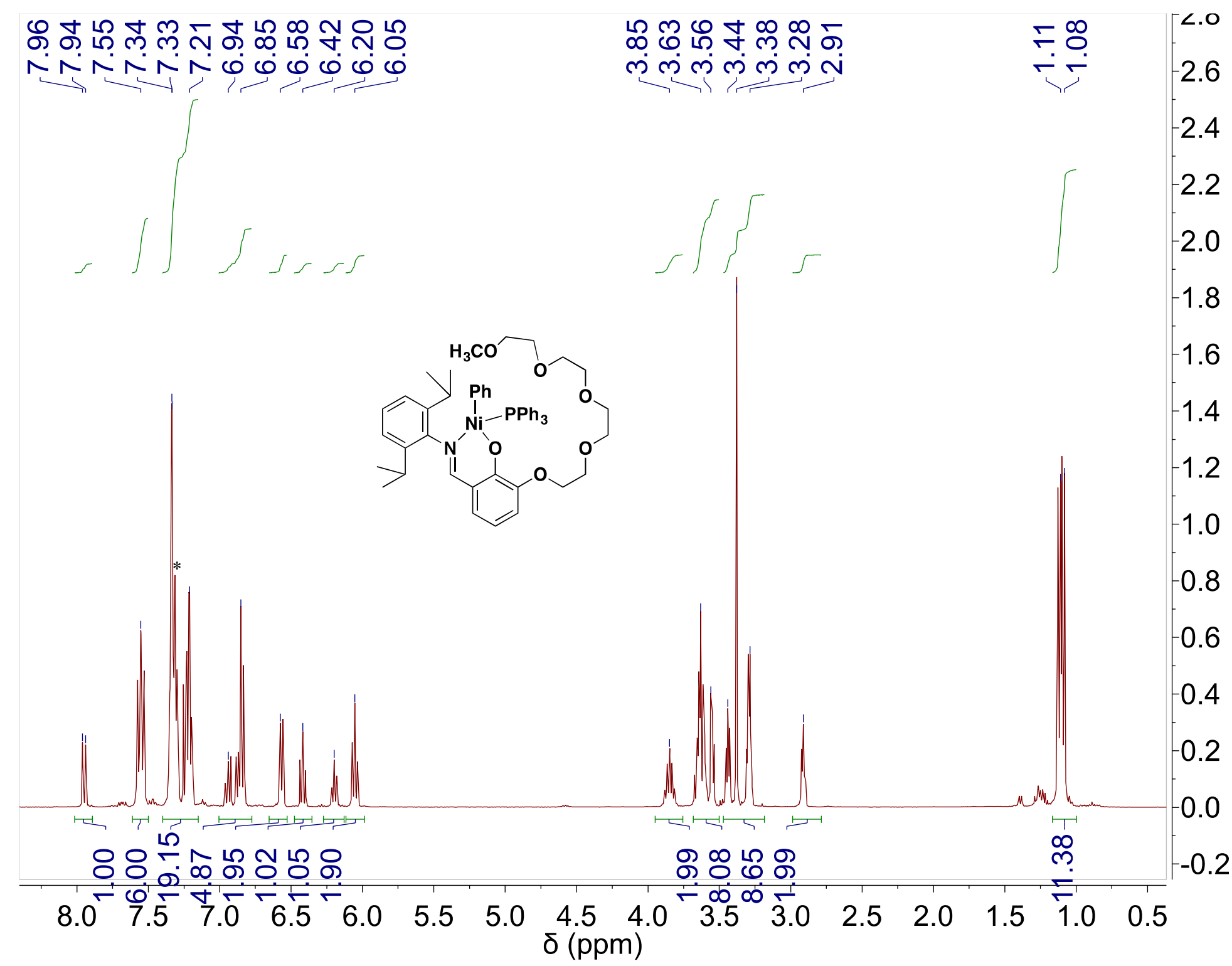

Figure S33. ${ }^{1} \mathrm{H}$ NMR spectrum $\left(\mathrm{CDCl}_{3}, 400 \mathrm{MHz}\right)$ of NiL4. Signals arising from a $\mathrm{PPh}_{3}$ impurity are marked with (*). 


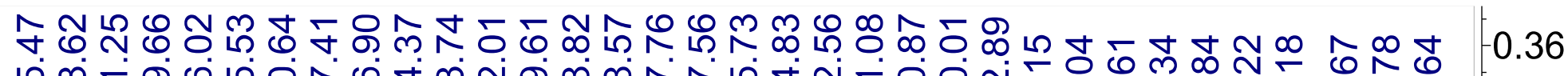

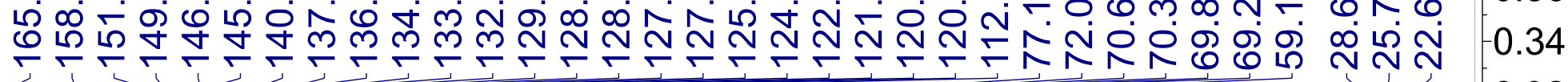

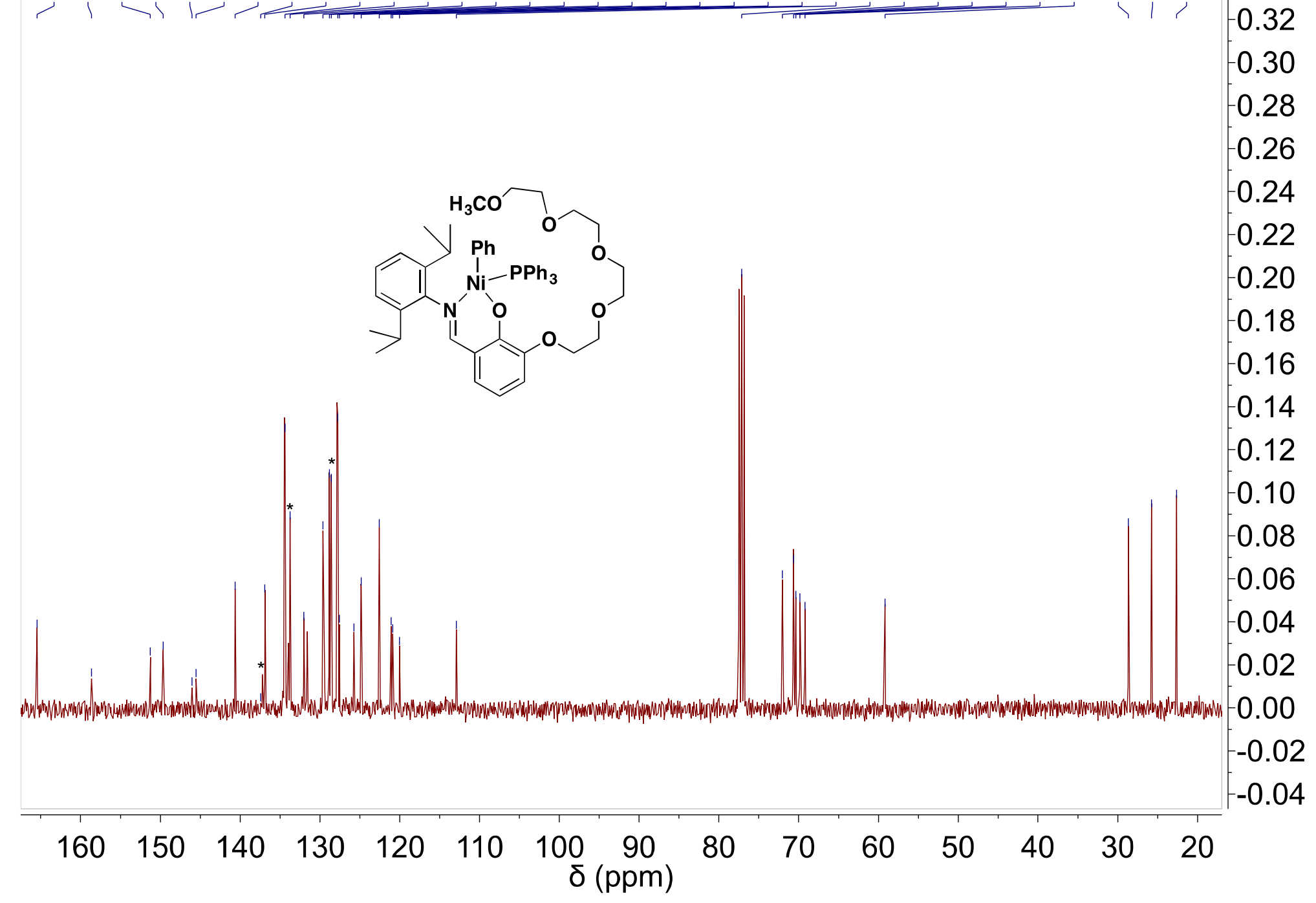

Figure S34. ${ }^{13} \mathrm{C}$ NMR spectrum $\left(\mathrm{CDCl}_{3}, 100 \mathrm{MHz}\right)$ of NiL4. Signals arising from a $\mathrm{PPh}_{3}$ impurity are marked with (*). 


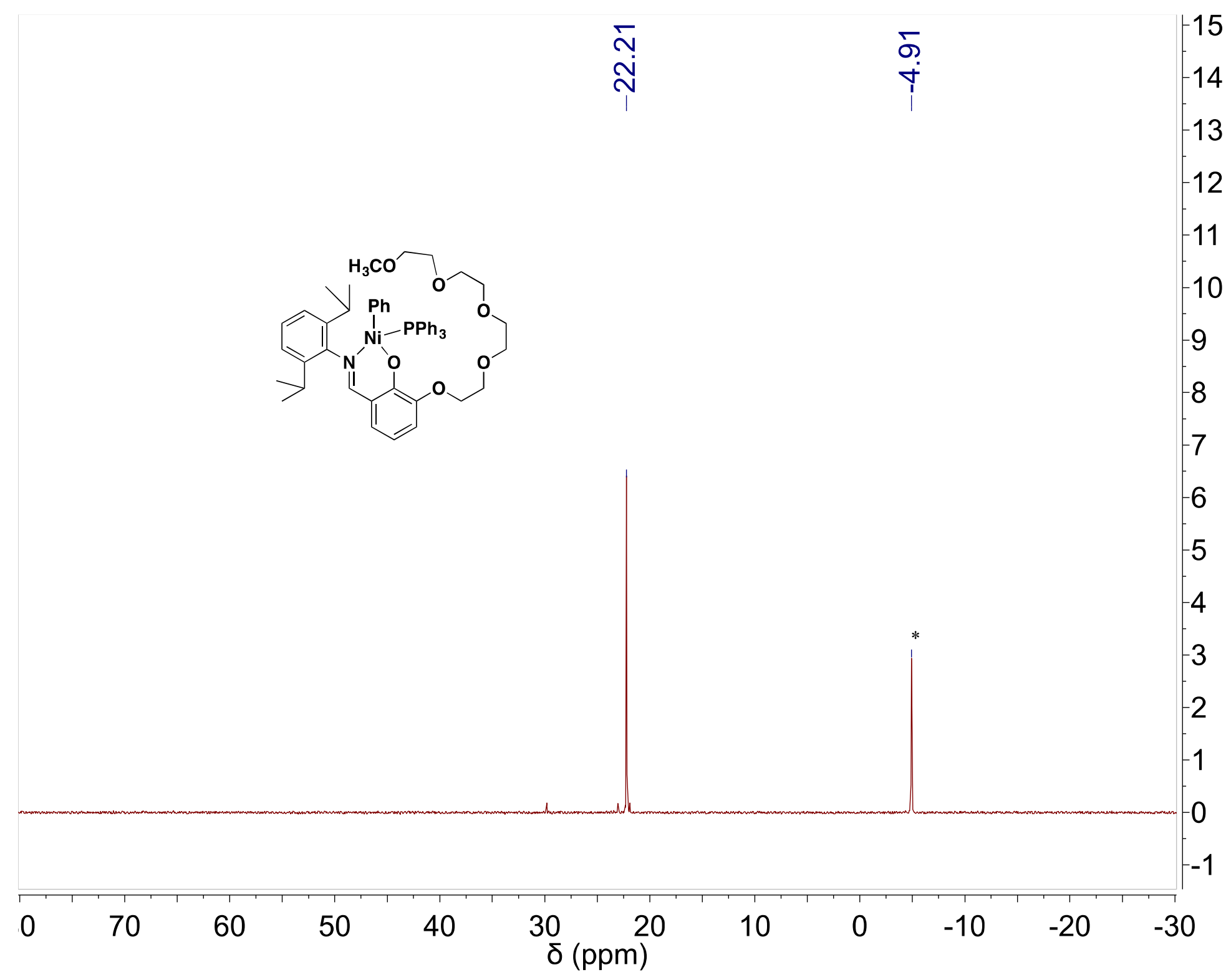

Figure S35. ${ }^{31} \mathrm{P}$ NMR spectrum $\left(\mathrm{CDCl}_{3}, 162 \mathrm{MHz}\right)$ of NiL4. The peak marked with (*) comes free $\mathrm{PPh}_{3}$ impurity. 


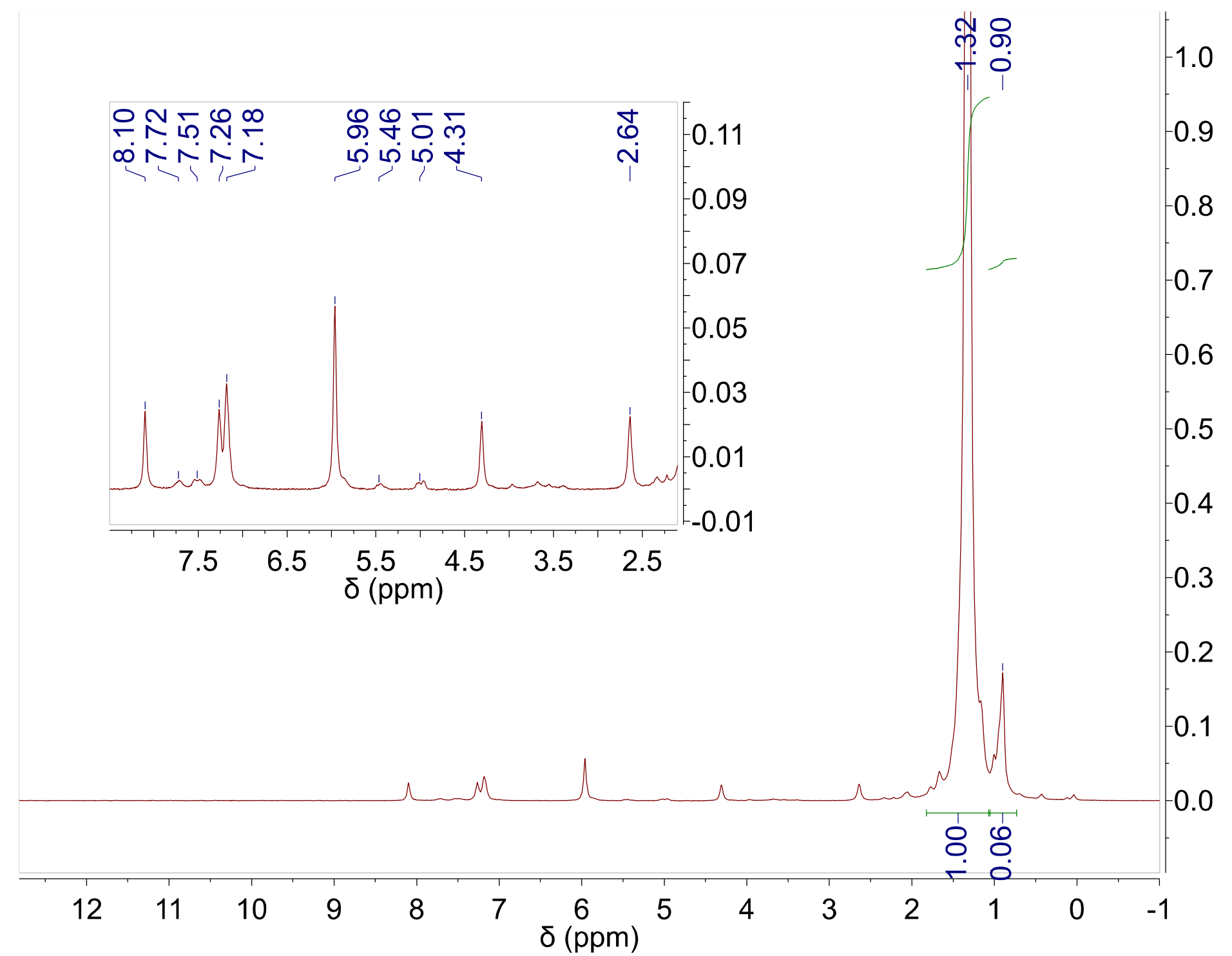

Figure S36. ${ }^{1} \mathrm{H}$ NMR spectrum $\left(\mathrm{TCE}-d_{2}, 600 \mathrm{MHz}\right.$ ) of the solid polyethylene obtained from the reaction of $\mathrm{NiL3} / \mathrm{Ni}(\mathrm{COD})_{2}$ in the presence of ethylene. Spectral assignments were based on the chemical shift valves reported in the literature. ${ }^{3}$ 


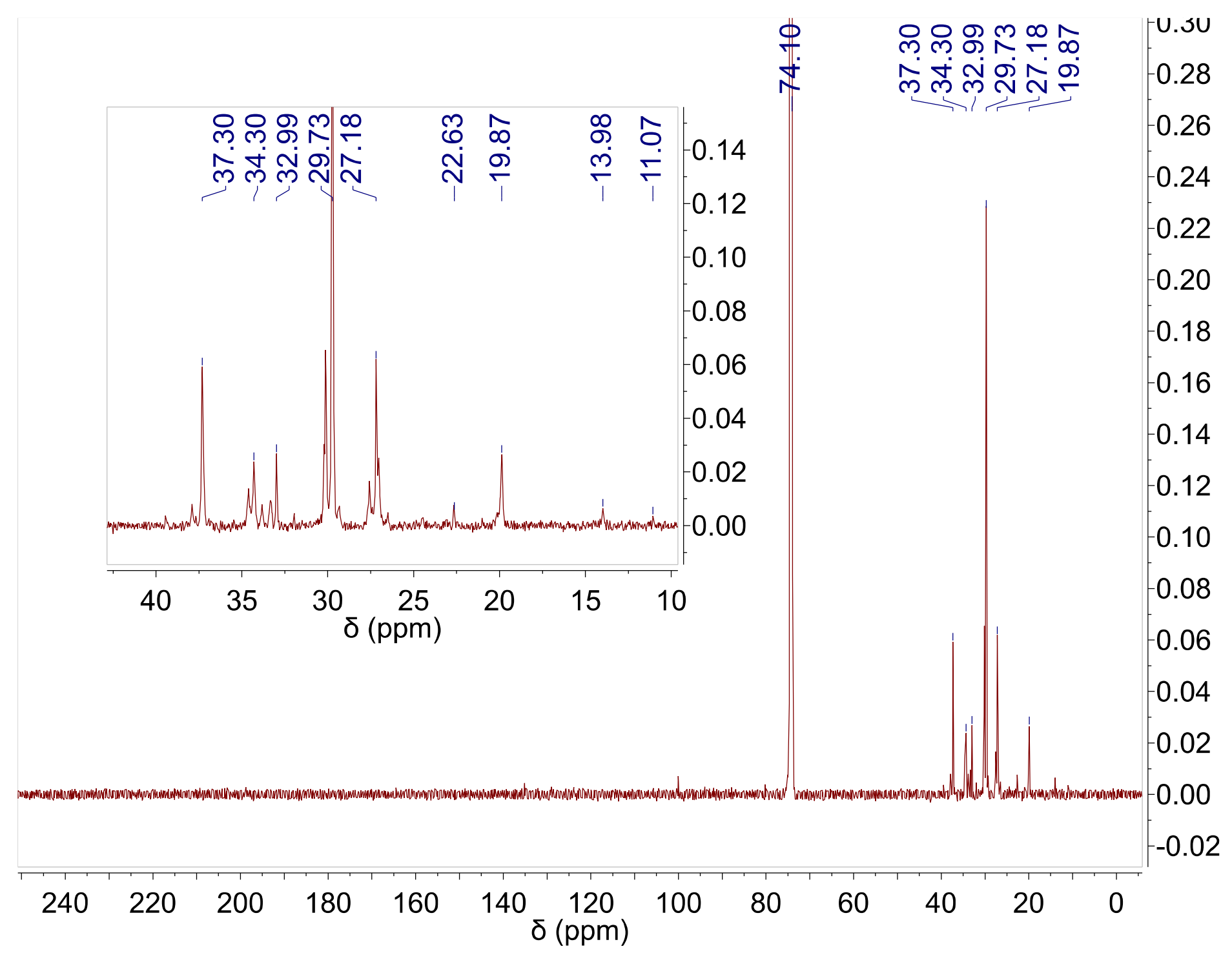

Figure S37. ${ }^{13} \mathrm{C}$ NMR spectrum $\left(\mathrm{TCE}-d_{2}, 150 \mathrm{MHz}\right)$ of the solid polyethylene obtained from the reaction of $\mathrm{NiL3} / \mathrm{Ni}(\mathrm{COD})_{2}$ in the presence of ethylene. Spectral assignments were based on the chemical shift valves reported in the literature. ${ }^{4,5}$ 


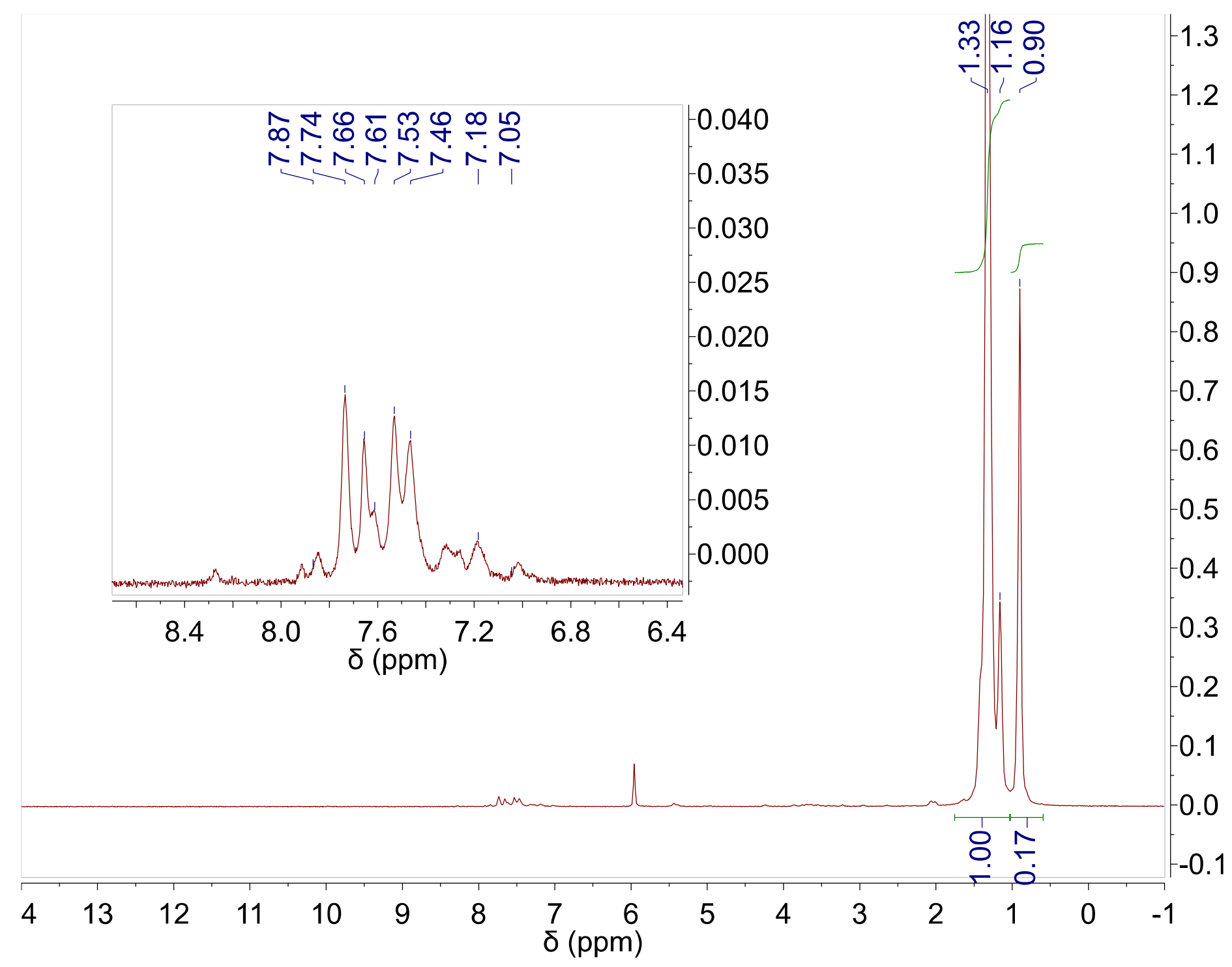

Figure S38. ${ }^{1} \mathrm{H}$ NMR spectrum (TCE- $\left.d_{2}, 600 \mathrm{MHz}\right)$ of the amorphous polyethylene obtained from the reaction of $\mathrm{NiL3} / \mathrm{NaBAr}_{4}{ }_{4} / \mathrm{Ni}(\mathrm{COD})_{2}$ in the presence of ethylene. Spectral assignments were based on the chemical shift valves reported in the literature. $^{3}$ 


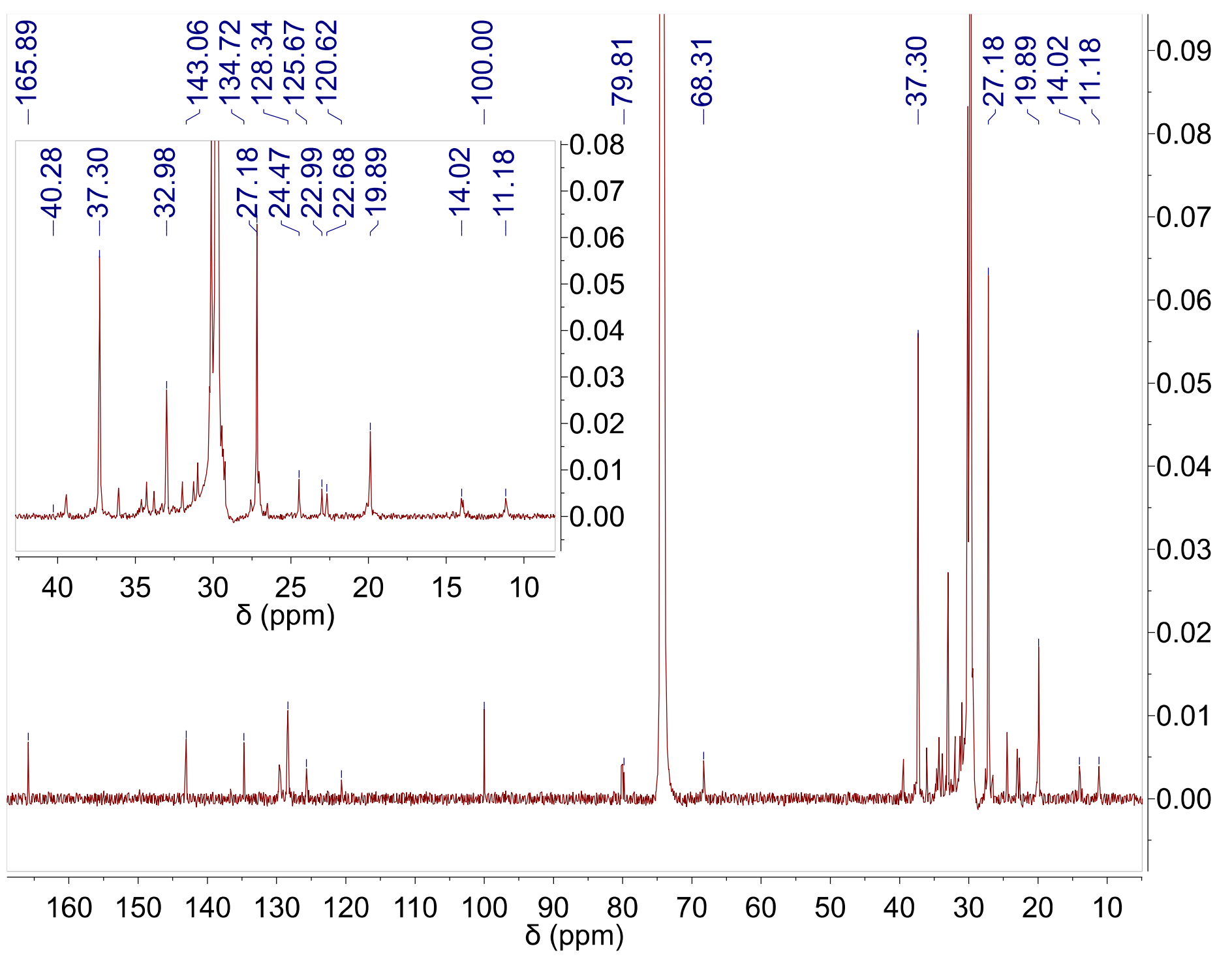

Figure S39. ${ }^{13} \mathrm{C}$ NMR spectrum $\left(\mathrm{TCE}-d_{2}, 150 \mathrm{MHz}\right)$ of the amorphous polyethylene obtained from the reaction of $\mathrm{NiL3} / \mathrm{NaBAr}_{4}{ }_{4} / \mathrm{Ni}(\mathrm{COD})_{2}$ in the presence of ethylene. Spectral assignments were based on the chemical shift valves reported in the literature. ${ }^{4,5}$ 


\section{References}

(1) Kita, M. R.; Miller, A. J. M. J. Am. Chem. Soc. 2014, 136, 14519.

(2) Kuzmic, P. Anal. Biochem. 1996, 237, 260.

(3) Hansen, E. W.; Blom, R.; Bade, O. M. Polym. 1997, 38, 4295.

(4) Galland, G. B.; de Souza, R. F.; Mauler, R. S.; Nunes, F. F. Macromolecules 1999, 32, 1620.

(5) Cotts, P. M.; Guan, Z.; McCord, E.; McLain, S. Macromolecules 2000, 33, 6945. 